\title{
- 宿题報告・
}

\section{農村における糖尿病の実態}

\author{
伊藤恭平 \\ 愛知県厚生連 愛北病院長 \\ 名古屋大学講 師

\section{協同研究者}

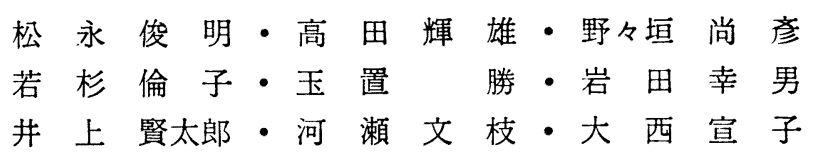

\section{目次}

はじめに

〔I 糖尿病の概念

(II]わが国に抢ける糖尿病の現況
(1) 死亡統計
(2) 実態調查

〔III〕農村に和ける糖尿病の実態とその特徽

(1) アンケート調查成績について
(i) 病院統計
(ii) 集団恮晾成樍

(2) 私どもの行なった疫学的調査並びに臨床的観察

(i) 外来・ 入院患者統㖕

(ii) 人間ドック統計

（iii）集団検㡣成績

〔IV]糖尿病早期診断とくにスクリーニング法について むすび

文 献

$$
\text { はじめに }
$$

今日糖尿病, Diabetes mellitus は, 脳卒中, 癌, 心 臟病など一連の成人病とならんで重要視されなければな らない成人病的性格をむった疾病の一つと思われる。一

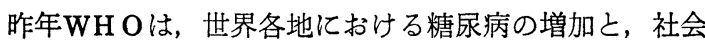
各階層への浸潤，あるいは若き勤労者層への渗透傾向の 増加にかんがみ，乙れが対策をとりあげており，一方わ が国においては昨年11月，「全国糖尿病週間」が始めて あうけられたのも，とうした公䍃衛生学的重要性が一般。
に認識されて来たためと思われる。

さて農村における糖尿病の実態は，今日なお判然とし ない点が極めて多い。現在糖尿病が社会各階層に拡がり つつあるという事実，すなわち糖尿病は従来特殊な階級 に多く, 肉体労㗢者化少いとされて来た点が, 農村にお いて今日いかなる变貌を示しつつあるかという問題汇関 しても，あるいはまた宿主侧の諸要因とか，生活環境， 地域別の差異についてむ，なお討論の域に達していない のが現状と思われる。

本学会において「農村における糖尿病」の性格乃至は 病態がとりあげられて来たのは，乙て数年前からに過ぎ ない。しかむ農村の現実の中で, 医学的な諸問題をとら え, 疾病の実態を明らかにするという農村医学的な見地 からの, 糖尿病の追究は現在漸く緒につきかけたばかり といって差支ない如くである。

以下私どもは農村における糖尿病の実態を, こうした 立場から観察してゆく one step として, この報告を致 したいと思う。

\section{〔I〕糖 尿病の概念}

さて農村における糖尿病を追労するにあたり，まず現 時点における「糖尿病の概念」について一言触れてみた い。糖尿病を簡単に定義することは甚だ困難ではある が，ともかく一般には「膵臓 Langerhans 氏島より分泌 される体内 Insulin 量の絶対的, 或いは相対的不足によ って生ずる慢性の機能的疾患」とすることが妥当の如く 思われる (表No. 1)。

これは臨床的には「高血糖, 尿糖など糖質代謝面での 
表No. 1

[ I ]

\section{定義 (1) 体内インスリンユの絶対的あ ろいは相対的不足によって生 ずる慢性の機能的疾息。 \\ (2)殹床的には㘣血精尿根な

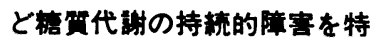 色とする揭合が多い。}

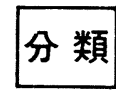

A（1）真性（䀠性）检尿病

(2) 䐙外性榶尿病

(a) 再性裾尿病

(b) 腆外性高血糖性 標尿病

(坂 口)

(B) （1）真性糦尿病

(原発性)

(2) 二次的精尿病 (㖣発性)

[Duncan]

持続的障害を特色とする場合」が多いと表現されるので ある。従来糖尿病は「糖尿, 口のかわき, 多飲, 多食, 多尿，るいそう」などの症状をあって定義ずけられて来 たのであるが，比較的早期に「血糖」が糖尿病を診断す るにあたり第一義的な意味を有することが確認されてよ り，今日ではむしろ血糖を中心とした代謝機能の検索が 重要視されており，「糖尿」は第二義的なもの之考えら れているかの如く思われる。

次に糖尿病は，「故坂口教授の分類」によれば，膵臓 性, 即ち真性糖尿病之, 膵臓以外の無害性糖尿即与腎性 糖尿及び膵外性, 高血糖性糖尿病にわけられており，ま た「Duncan」は，遗伝に原因する狭義の真性糖尿病と， 膵裁及び膵臓以外の内分泌腺, 肝臟などの病変とか, 或 いはステロイド投与などによって生ずる比較的原因の明 らかな, 二次的, 続発性の糖尿病に分類 している（表 No. 1)。

さらに「病期」よりみると，褈床的に糖尿病を証明し 得ない発病前期のあのを Prediabetes. コーチゾン, ブ ドー糖負荷試験等で, 糖代謝機能に異常を認めやすいと される latent chemical diabetes. また糖代謝面で多少
とも異常が認められるが，臨床上無症状を示し，わが国 で最も多い chemical diabetes. ついで臨床的に明確な 異常を示す clinical diabetes. とに分類されている(Camerini D'avalos. 表No. 2)。

ともあれ糖尿病は, 遗伝因子, 人種などの先天的素因 に, 生活環境, 特に食生活, 年令, 肥満, 妊娠, 精神 的, 身体的ストレス, 各種の薬物使用などの後天的諸团 子が加わって, 発症するに至るすのと, 今日理解されて いる (表No. 2)。

ての報告においては時間の制約上, 真性, 膵臓性糖尿 病についてのみ言及致したい。

表No. 2

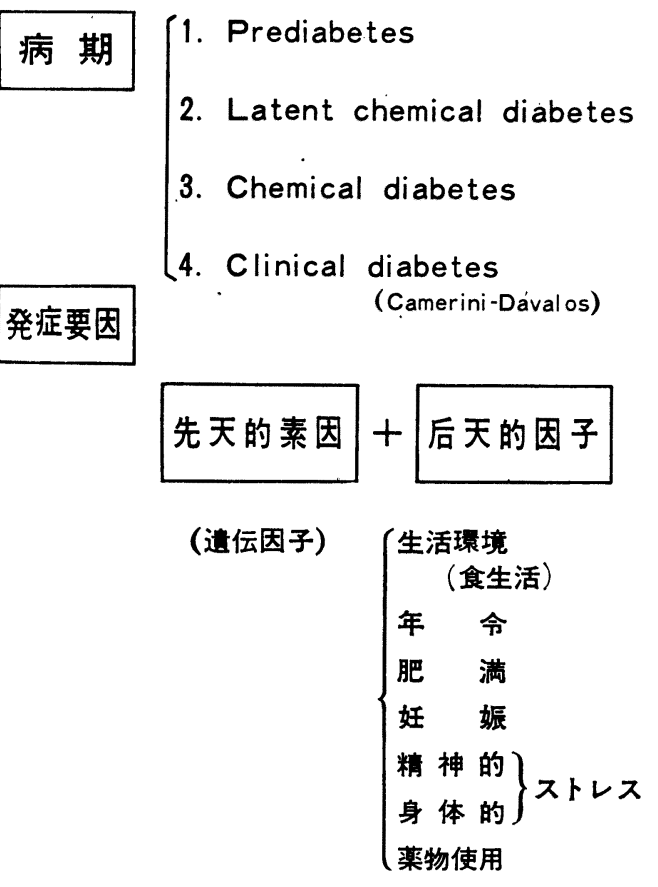

〔II〕わが国における楛尿病の現況

(1) 死亡 瑹計

さて農村における糖尿病の実態を理解するには，まず わが国における糖尿病の現況を知る必要がある。最初に 「死因別統計」(表No. 3) について観察する。従来わが 国においては, 糖尿病は比較的少い之されているが, 事 実死因別統計よりみると, 昭和38年度における全国統計 では, 糖尿病死は 3,980 名で, 総死亡 67 万 770 名のわずか 0.59\%ににすぎない。ただ欧米諸国とひとしく，女性の死 
表No. 3 死因別統計

（全 国）

\begin{tabular}{c|c|c}
\hline & 総 死亡 & 糖 尿 病 \\
\hline 全 & $\begin{array}{r}361,469 \\
(765.3)\end{array}$ & $\begin{array}{r}1814 \\
(3.8)\end{array}$ \\
\hline 早 & $\begin{array}{r}309,301 \\
(632.2)\end{array}$ & $\begin{array}{r}2166 \\
(4.4)\end{array}$ \\
\hline 計 & 670,770 & $\begin{array}{r}3980 \\
(0.59 \%)\end{array}$ \\
\hline \multicolumn{2}{|c|}{$($ ) 人口10万对 (昭38) }
\end{tabular}

(愛知県)

\begin{tabular}{c|c|c|c}
\hline & 昭 3 7 & 昭 3 8 & 昭 39 \\
\hline$\hat{\delta}$ & $\begin{array}{c}75 \\
(3.4)\end{array}$ & $\begin{array}{c}79 \\
(3.5)\end{array}$ & $\begin{array}{c}82 \\
(3.5)\end{array}$ \\
\hline ㅇ & $\begin{array}{c}88 \\
(3.9)\end{array}$ & $\begin{array}{c}114 \\
(5.0)\end{array}$ & $\begin{array}{c}119 \\
(5.0)\end{array}$ \\
\hline 計 & $\frac{163}{29,413}$ & $\frac{193}{27,852}$ & $\frac{201}{27,665}$
\end{tabular}

亡率が男性より多くなって来ているてとは注目すべきて とと思われる。

また私どもの居住する愛知県においても，昭和 39 年度 におりる死亡率は総死亡の $0.73 \%$ ，人口 $10 万$ あたり男 3.5 人，女 5 人之，全国統計に匹敵する成績が示されて いる。

次に「糖尿病死亡率の年次的変化」(図No. 1) をみる と，糖尿病は一国の文化，経済状態を反映するとされる

図No.１＼cjkstart糖尿病死亡統計の年次的変化

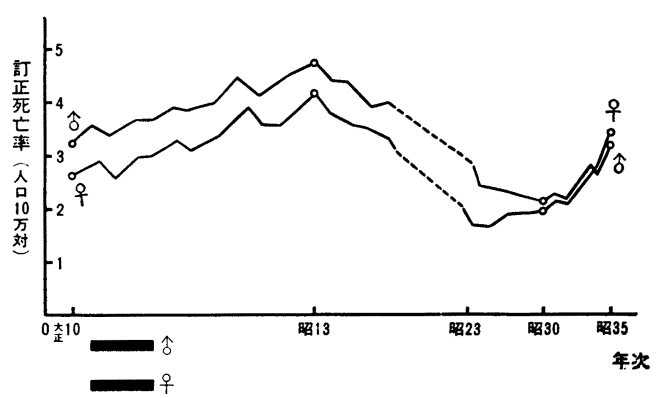

が，その訂正死亡率では昭和13年頃を頂点とし，ついで 第 2 次大戦に入ってからは減少を示し，敗戦後の昭和 23 年頃には最低となっている。以後昭和 30 年頃より男女ほ ほ平行して，上昇を辿っている如くである。

図No. 2 職業別桾尿病死亡率

（男）

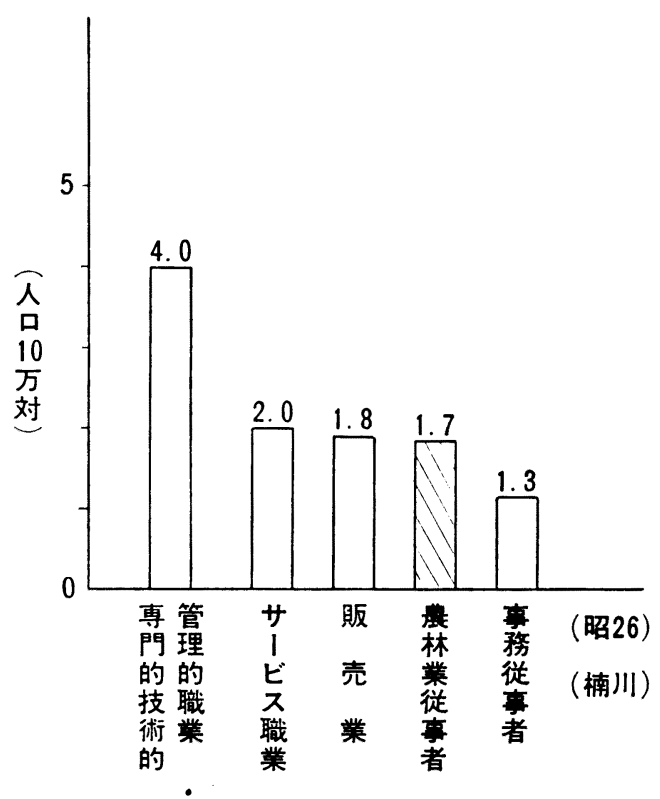

図No.３ 地域別糖尿病死亡率

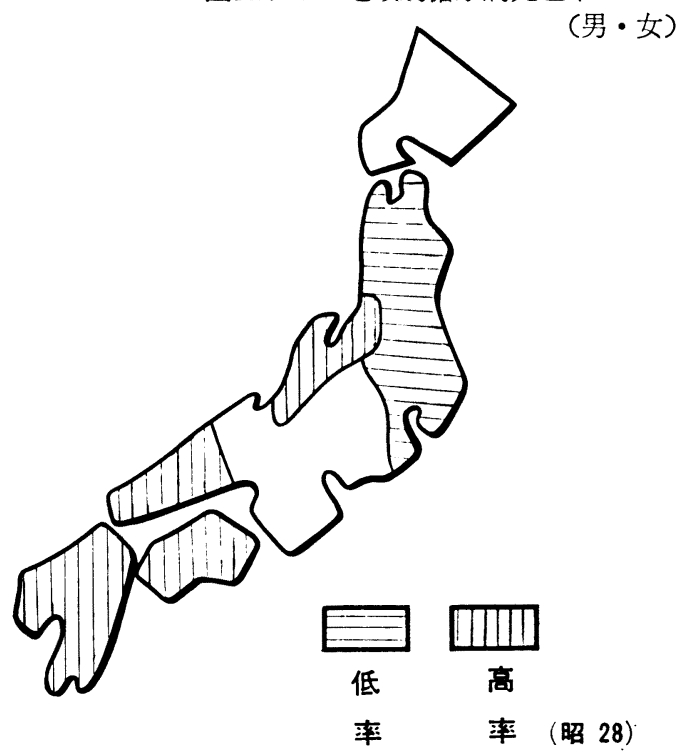


さらに「職業別死亡率」をみると（四No. 2), 男では 農林業従事者は, 専門的, 技術的, 管理的職業に比し, きわめて低率を示している。一方「地域的」に死亡率を みると (図No. 3), 北陸, 中国, 四国, 九州では男女を 通じて死亡率が高く, 関東以北, 大都市周辺では比較的 死亡率は低い様である。

以上死亡統計を通じていえることは，

(1)わが国における糖尿病死亡率は欧米に比し, 極めて 低い。

(2)農林業従事者の死亡率は高くない。

(3)糖尿病の死亡率をむって，わが国の糖尿病患者を推 定することは，糖尿渖が符一死因として分類される よりも，むしろ慢性合併症がその人の第一死因とし て記载される場合が多く，糖尿病がおおいかくされ る傾向が強く，糖尿病の実態を正確に示すとはいえ ない。

というととになりそうである。

\section{(2) 実的調查}

しかしながら现時点において，わが国の糖尿病発生頻 度を疫学的に正確に把握するととも，糖尿病が種々の発 症要因の影響を受けることが多いという点よりみて, 極 めて困難であるといえる。しかるわが国全人口中の糖尿 病䍜病率を推計するには日本人の全人口が無作為抽出に あうように層別化されたものについて，全例調查するて とが必要であり, 到底実施し得るものとは思われない。 しかしながら糖㽷病の增加傾向を知るという点に限るな らば, 昭和 31 年故勝沼精蔵教授を班長上して, 糖尿病研 究班が組織され全国的に集団検彰が实施されたてとは， 糖尿病疫学上，極めて重大な意義を有するものと考えら れる。

次に糖沓病研究班の「集団検沴検查方法」について触 れてみたい。乙の方法は（表No. 4)，「第一次」，「第二 次」検查にわけられ，「第一次」検查はスクリーニング 法である。即ち朝, 充分食事をとり，2 ないし 3 時間 後, 血榶, 尿傏を测定する。その判定は, 血糖 $140 \mathrm{mg} /$ $\mathrm{d} 1$ 以上，尿糖陽性を異常とし，そのすべてを第二次検査 にまわす。なお，血榶は Hagedorn-Jensen 氏法により， 耳染より採血，尿糖は Tes-Tape 法による。静脈血のさ いはSomogyi-Nelson 氏法により，かつ Hagedorn-Jensen 氏法の値より $20 \mathrm{mg} / \mathrm{dl}$ 減じた值を標準とする。

「第二次検查」は, 第一次検查異常者に, 米飯 $300 \mathrm{~g}$ 以上の，いわゆる「飽食試験」を施行し，血糖は朝食 前, 食後 2.3 時間，尿糖は食後 2 時間に测定し，血糖 が食後 2.3 時間とも $140 \mathrm{mg} / \mathrm{dl}$ 以上を「糖尿病」， 2 . 3 時間の一方が $140 \mathrm{mg} / \mathrm{dl}$ 以上を「疑糖尿病」, しからざ
表No. 4 糖尿病集団検診検查方法（糖尿病研究班）

\begin{tabular}{|c|c|c|c|}
\hline 検 查 & 法 & 半 & 定 \\
\hline 第 1 次 & 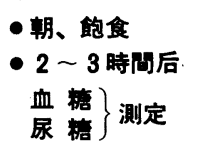 & - 血 & $\begin{array}{l}\text { 糖 } \geqq 140 \mathrm{mg} / \mathrm{dl} \\
\text { Hagedorn-Jensen) } \\
\text { 糖 }(+) \\
\text { 暴 }\end{array}$ \\
\hline \multirow{3}{*}{ 第 2次 } & \multirow{3}{*}{ 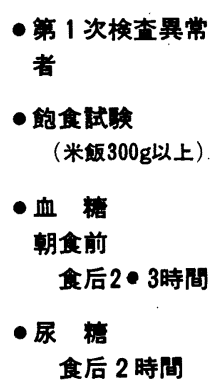 } & $\begin{array}{l}\text { 糖 } \\
\text { 尿 } \\
\text { 病 }\end{array}$ & $\begin{array}{l}\text { - 血 榶 } \\
2 \cdot 3 \text { 時成とも } \\
\geqq 140 \mathrm{mg} / \mathrm{d} \ell\end{array}$ \\
\hline & & $\begin{array}{l}\text { 同 } \\
\text { 疑 }\end{array}$ & $\begin{array}{l}\text { - 血 糖 } \\
2 \cdot 3 \text { 時間の一方 } \\
\geqq 140 \mathrm{mg} / \mathrm{dl}\end{array}$ \\
\hline & & $\begin{array}{l}\text { 非 } \\
\text { 糖 } \\
\text { 尿 }\end{array}$ & $\begin{array}{l}\text { - 血 糖 } \\
2 \cdot 3 \text { 時間とも } \\
<<139 \mathrm{mg} / \mathrm{d} d\end{array}$ \\
\hline
\end{tabular}

るあのを「非糖尿病」と判定するのである。この際, 最 高血糖值， 1 時間值については基準がなく，また糖尿の 有無む㟝断上考虑されていないが，ての判定基準は現在 直ちに変更する理由に乏しいとされている。

さて, かかる方法で「発見された糖尿病」は, 昭和 32 年から33年においては, 小林教授の報告（図No. 4) 飞 よると, 30 才以上, 糖尿病 $4.8 \%$, 疑糖尿病 $2.7 \%$, さら に同一症例の一部についての観察では, 昭和37年度糖尿

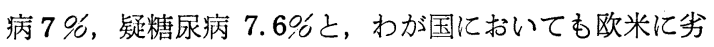
らない発生頻度が得られており, しかす年令と共に増加 傾向を示すととがわかったのである。

また「男女別」では, 男性がやや多い発見率を示して いる (図No. 4)。

次に「年代別の糖尿病発見率」をみると(図No. 5), 糖 尿病, 疑糖尿病とむ年令のすすむにつれ, 明らかに上昇 を示し，70才代糖尿病8.2\%，60才代 7.79\%，50才代 5.8 宁と, 成人病的な性格が強いという成績が示されてい る。

次に「地域別の糖尿病発見率」では (四No. 6), 北 陸, 東京の各 $5.4 \%$ を最高に, 最低は四国の $2.4 \%$ とと いう成績で, 前にのべた糖尿病死亡率とは, かなり異っ た成績を示している。

次に「職業別糖尿病発見率」では（図No. 7)，乙の検 診の対象は，一部地域住民を含んではいるが，多くは官 宁，会社，工場など特定集団であるため，成績に歪みが 
図No. 6 集団検診之地域別発見率

図No４４発 見 率（集団検䛦）

(昭34年)

( 30 †以上)

(小林)
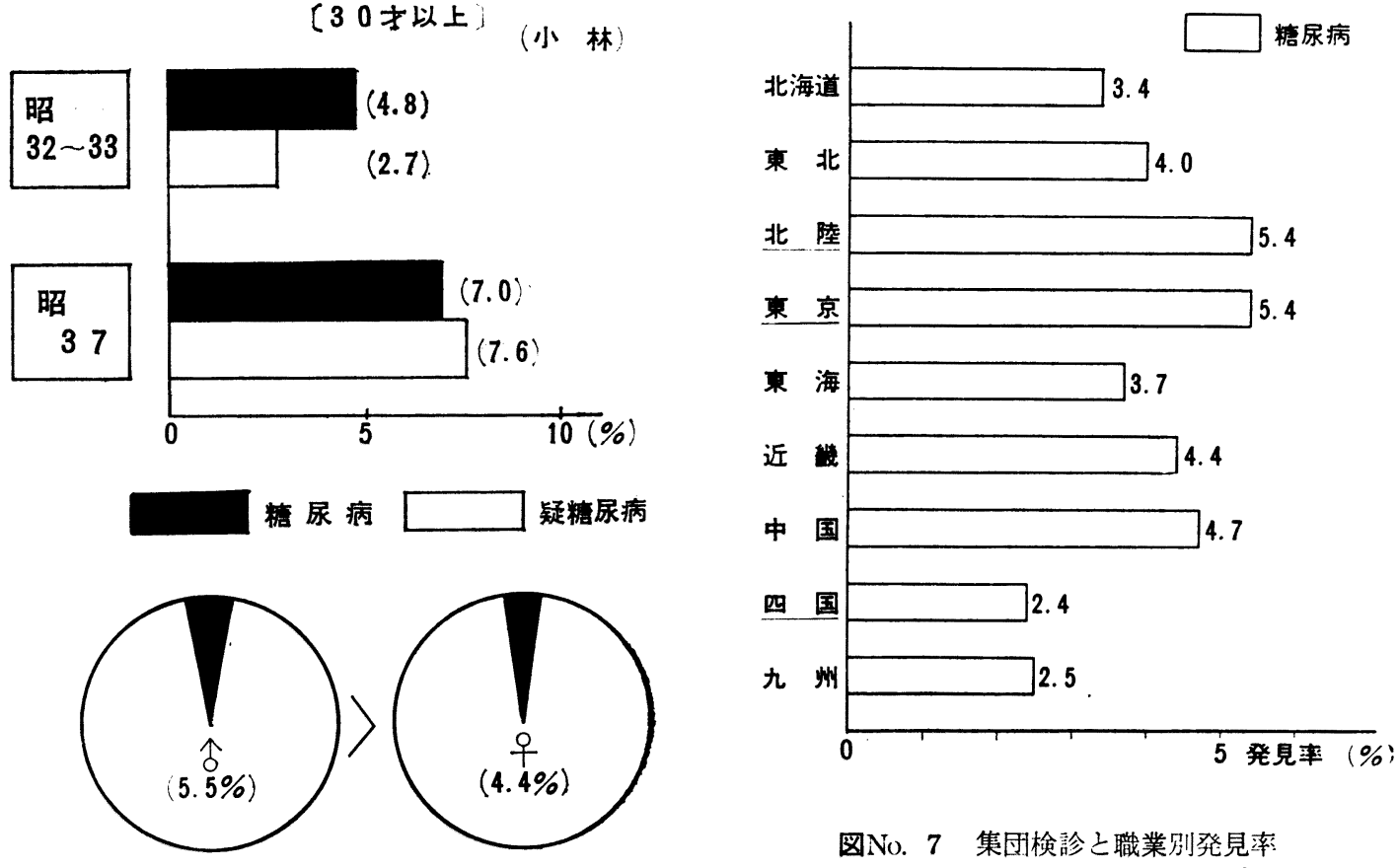

図NNo.７集団検診之職業別発見率

（昭34年）

図No. 5 集団検診と年代別発見率
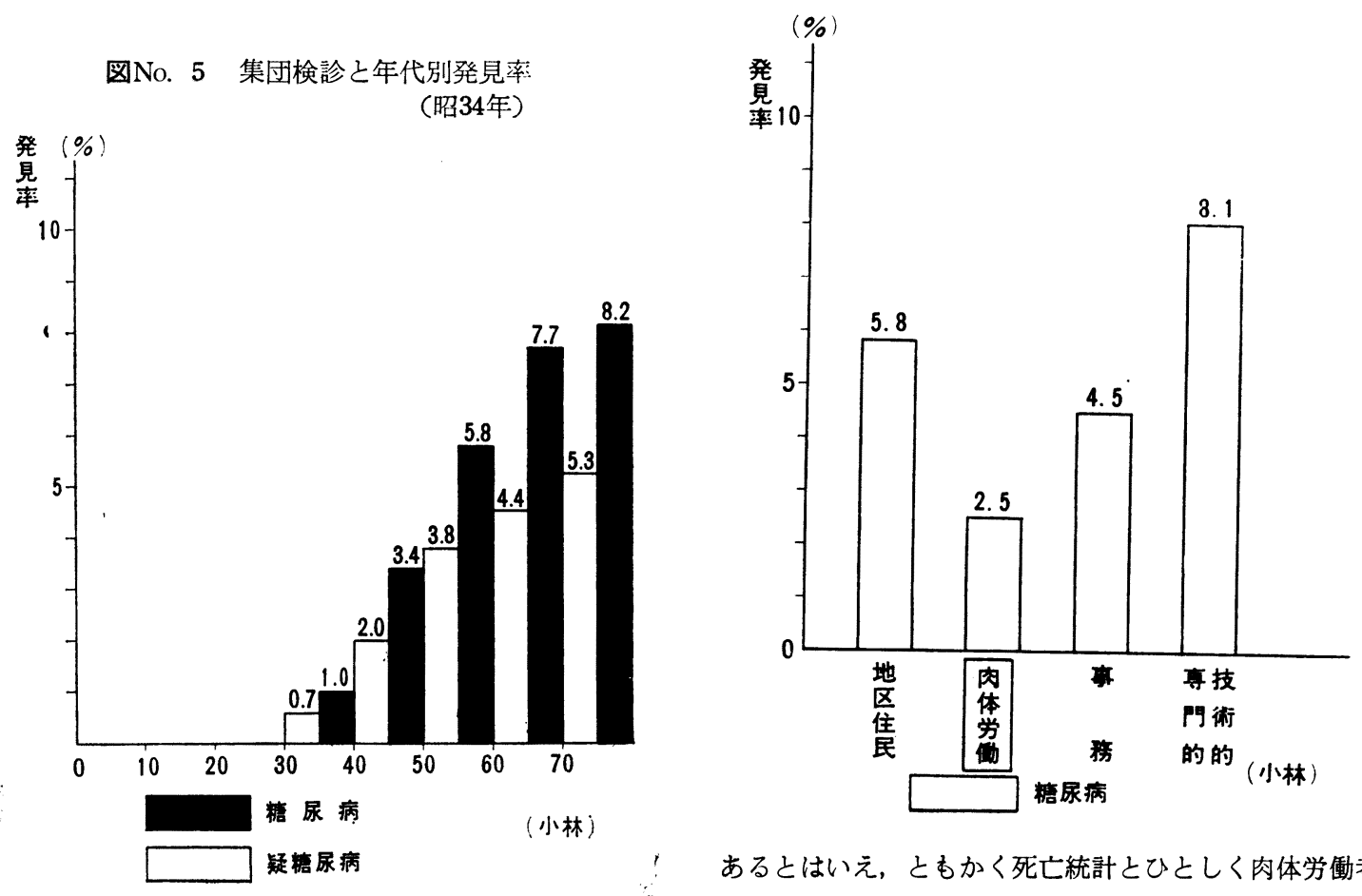

あるとはいえ，ともかく死亡統計とひとしく内体労働者 の発見率は $2.5 \%$ \%，職業別の格差はやはり強い如くで 
ある:

亡らに糖尿病は，発症上「遣伝，肥満」との関連が強 く，また「動脈硬化ないしは高血圧」を伴う場合が多い のであるが, 糖尿病発見率むまたてれら 3 者を証明しう る者からは，高率に発見されている（四No. 8)。またそ の $\frac{4}{5}$ 強は,「未知の発見患者」で (罒No. 8), 潜在性, 無自覚性, 未知糖尿病患者が如何に多いか理解されるで あろう。

以上糖尿病研究班の成績をとりま之めてみると，

(1)わが国において糖尿病は少ないという在来の見解は 妥当性に乏しい。

(2)年代の増加之共に糖尿病は増加し，しかも若年層の 増加傾向も存在する。

(3)が国における糖尿病の男女比が欧米之同じく接近 し, 将来は逆転も予想される。

(4)末知, 無自覚性糖尿病が極めて多いととなどである。

図No．８発見率と高血圧症, 肥満, 遺伝との 関係及び既知・未知糖尿病について
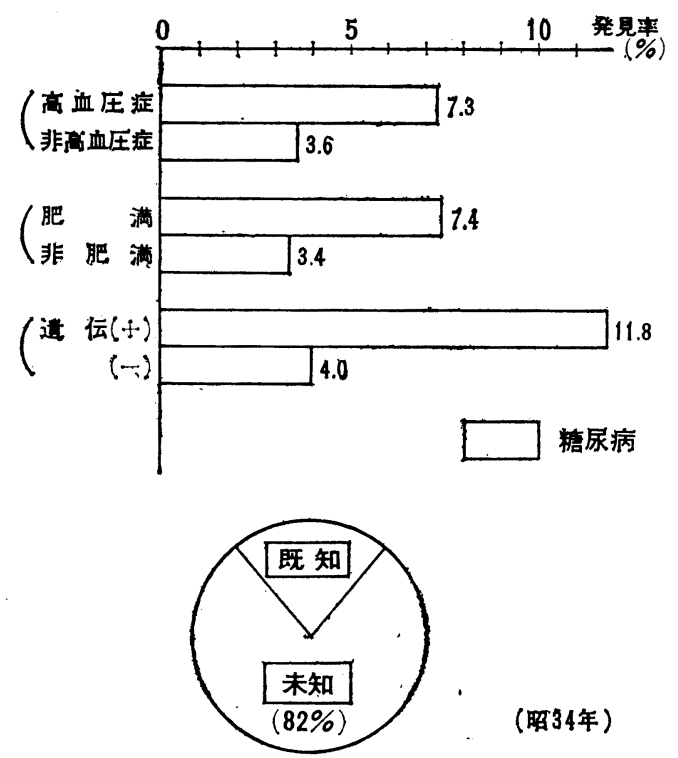

(昭34年)

\section{〔III〕農村における諾尿病の実態とその特徽}

以上わが国における糖尿病の概況について観察した が, しからばてうした現状と比較して, 農村における糖 㽷病は如何なる実態を示しているであろうか。以下本論 に入るとととする。

その調查方法として, 私どあは,

(1)農村を主な診療圈とされ，或いは農村において糖尿
病実態調査を施行されたことのある全国各大学, 各 病院にアンケートを送り, その羅病率, 集団検搒発 見率, 病態などから地域的な分布, 諸発症要因など を観察する方法と

(2)私どあの病院における受㟝患者, 人間ドック受診者 の病態,さらには愛知県尾張部の様々な農村地域で 集団検診を施行した結果を観察する方法 とに大別して調査した。

\section{(1) アンケート調查成績について}

さてアンケート調査に御回答いただいた機関の数は各 病院における受診者の統計調査ならびに集団検診調査を ば合計して，27機関であり，その分布はほぼ全国にまた がっておるといえる（表No. 5)。

表No. 5 アンケート回答施設数

\begin{tabular}{c|c|c|c}
\hline & 病院統計 & 集団検診 & 計 \\
\hline 北海道 & & 2 & 2 \\
\hline 東 北 & 3 & 2 & 5 \\
\hline 関 東 & 1 &. & 1 \\
\hline 信 越 & & 1 & 1 \\
\hline 東 海 & 7 & 3 & 10 \\
\hline 近 韯 & 1 & & 1 \\
\hline 中 国 & 2 & 1 & 3 \\
\hline 四 国 & & 1 & 1 \\
\hline 九 州 & 2 & 1 & 3 \\
\hline 計 & 16 & 11 & 27
\end{tabular}

(i) 病院統計

最初に各機関における「外来及び入院患者に対する糖 㽷病の罹病率」をみると（四No. 9), 外来では0.11\%か ら15.5\%。公院患者では $0.23 \%$ から $22.63 \%$ と極めて大き な変動が認められるが, 概して外来では $2 \%$ 以内の䍜病 率, 入院では $6 \%$ 以内罹病率が多い如くである。てう した变動は外来においては，その機関における受診患者 の質的，量的な差異，ならびに糖尿病に対する発見方法 のあり方などに関連がある如く思われる。例えば糖尿病 専門外来の設けられている機関においては, 当然その罹 病率は高いわけである。

次に「外来及び入院糖尿病患者にみられる特長」につ いて二, 三図示致したい。

第一に糖尿病患者の「性別」であるが，糖尿病研究班 
図NO. 9 糖㽷病惟病率（病院統計）

(病院統計)
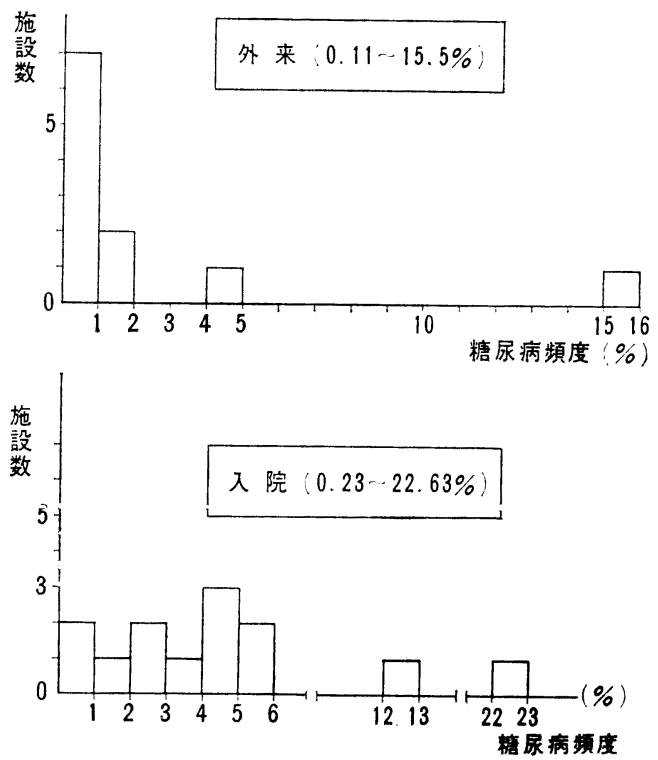

の成績に比し，男性が $60.2 \%$ とかなり多数を示している (困No. 10)。

また「年代別」では50才代が最高という施設が多く，つ いで60才代，40才代という順を示している（図No. 10）。 次に「職業別分布」をみると（図No. 11），乙れも受 診者の層, 地域的な差異む加わるとはいえ, 非農家が農 家より多い成績である。

さらに「合併症」では, 糖㽷病の特色である血管障害 が最む多く，ついで感染症，神 経 障害の順となってい る(図No. 11)。

以上の成績をとりまとめてみると，外来，入院患者に みられる糖尿病の統計では,

(1)罹病率は各々の機関の施設とか, 糖尿病発見方法例

えば検尿の方法，回数などにより，かなりの差異が みられ，実態がつかみにくい。

(2)糖尿病は成人層に多く，合併症には血管障害が多い ということになるのである。

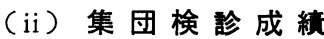

次に農村における集団検診調査ではいかなる成績が示 されているかという点に移りたい。

まず「集団検診の実施された地域」は（図No. 12）, 関東，近畿，北陸を除いた各地域であり，また集団検診 の実施期間は，昭和32年から41年の間であるが，ともか く 7 地域，11機関に及んでいる。
図No. 10 特徵 （病院統計）

性 別
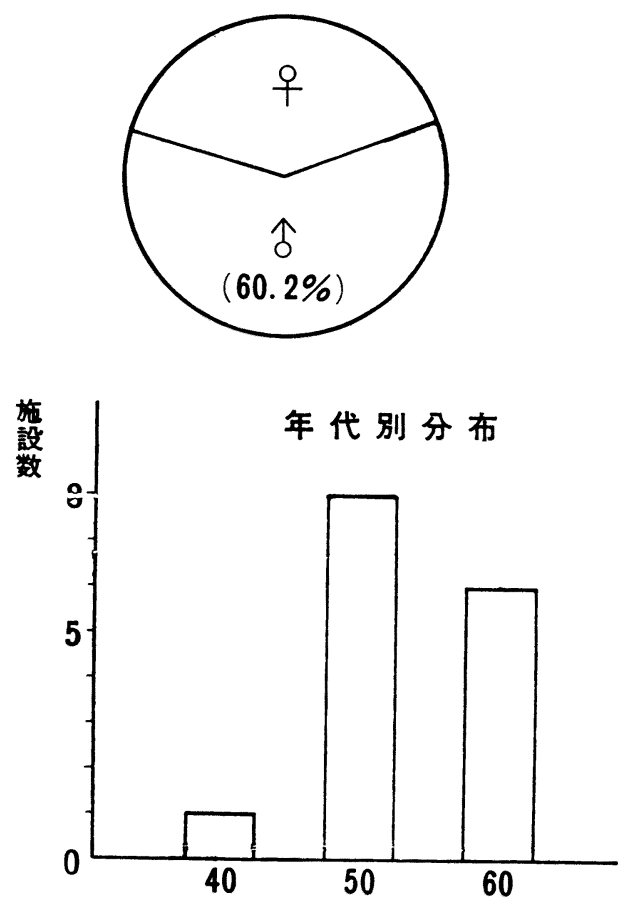

図No. 11 特 徴 (疮院統計)

職業別分布

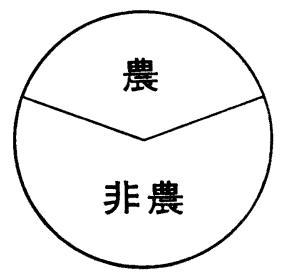

合 併 症

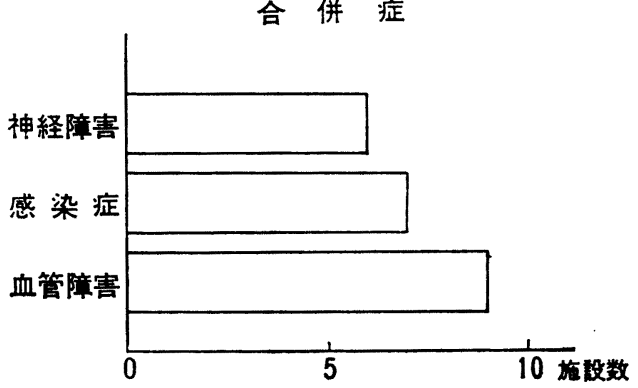


図№. 12 集団榆彭実施地区

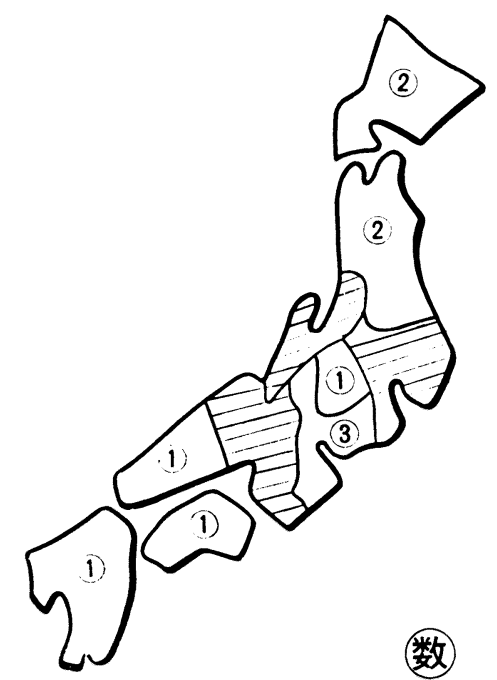

さてこの「発見率」は，全施設についてみる上（図 No. 13), 糖尿病は 0.6\%加ら 5.5\%, 疑糖尿病は $0.14 \%$ から $5.3 \%$ と, 病院統計とひとしく, 变動が極めて大で ある。また同一地方における成績でも, 東海地方では比 較的動摇範囲が少ないのであるが, 東北, 北海道ではか なりの差異が認められる。かかる変動は, 糖尿病の集団 検診任際しての調查方法, 判定方法が必ずしも統一され ていないことが主因の如く思われる。例えば第一次検查 沉おいて血糖, 尿糖の併用か, 尿糖のみかというスクリ 一ニング法の差, 或いは第二次検查において糖負荷法が 米飯か，ブドー糖かという差などが関係している如くで ある。

即ち農村にお汀る糖尿病発生頻度を比較するには，そ の方法論における問題点がまず除外されなければならな い之いう感が大きいのである。

そこでこれらの集団検診調查のうち，対象地域を厳密 亿農村に限定し，かつ検査対象を40才以上の男女とし， しかも検查方法を糖尿病研究班の方法によった成績のみ に限って観察すると（図No. 14），今度は「全国的に極 わて類似した成績」が得られるのである。即ち糖尿病は $3.3 \%$ から $5.5 \%$ ，疑糖尿病は $3 \%$ から $5.3 \%$, 昭和 32 年から33年度における糖尿病研究班の成績に匹敵してく るのである。しかも死亡統計で述へた如く，集団検診で お, 中国, 四国, 九州で高く，東海，北海道ではやや低 い成績が得られる。とああれ，乙の因に示す如く，農村 においてす糖尿病は全国的に増加を示しておるといえる のである。

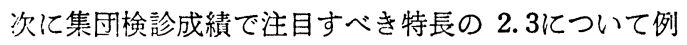

図No.13糖尿病発見率（集団検診全施設）

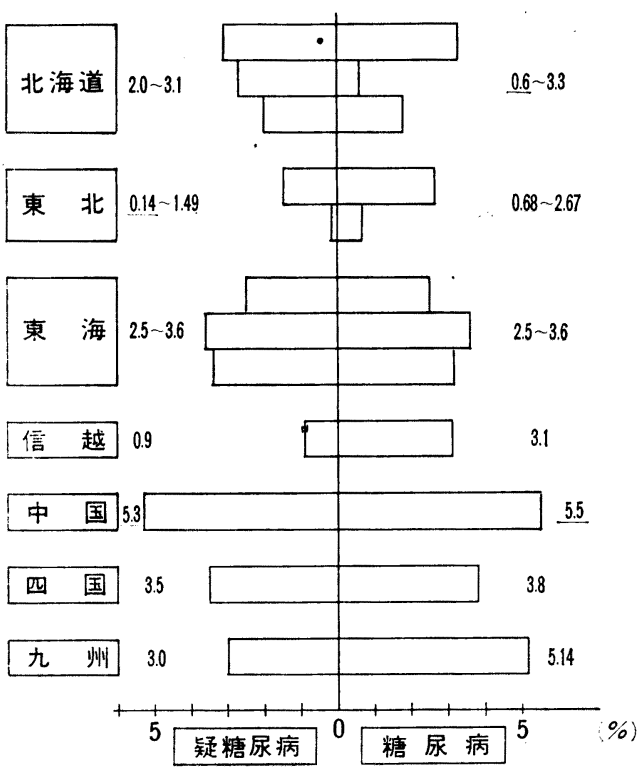

図No. 14 䅯尿病発見率（集団検㧸）

\begin{tabular}{|c|c|}
\hline O対象地域 & 奉 \\
\hline O検 查対象 & 40 才以上. 男女 \\
\hline ○検査方法 & $\begin{array}{l}\text { 糖尿病研究班に } \\
\text { よる }\end{array}$ \\
\hline
\end{tabular}

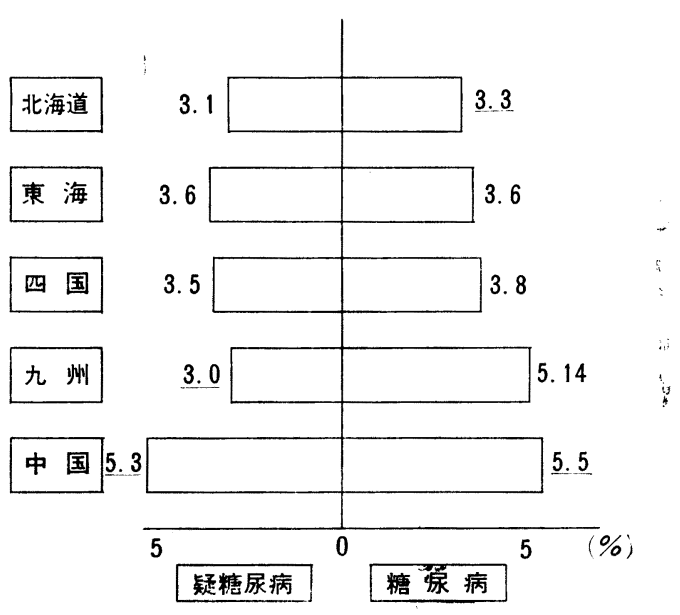

示する。

まず「性別」であるが（図No. 15)，やはり男性が優 位を示している。一方「年代別分布」では, 糖尿病は $50,60,70$ 才代と, 年令と共に增加し, 疑糖尿病では70 才代が最多となっておる（四No. 15）。 
次に「未知，既知患者比」では（図No. 21），未知患 者が告強を示し, いづれの統計とも共通の成績を示して いる。さらに「合併症」の頻度は（図No. 16), 病院統 計とひとしく，血管障害が最多を占め，特に高血圧，心 電図異常, 眼障害, 蛋白尿という合併症の比率が大で, ついで神経障害，感染症の順となっている(図No. 16)。

以上の成績をとりまとめてみると，

(1) 農村においても糖尿病の発生頻度は決して少なく ない。

(2) 従来の農業従事者にみられた糖尿病罹病率とは逆 に，農村においても現在糖尿病の浸潤傾向は大き

図No. 15 特 徵（集団検診）

性 別
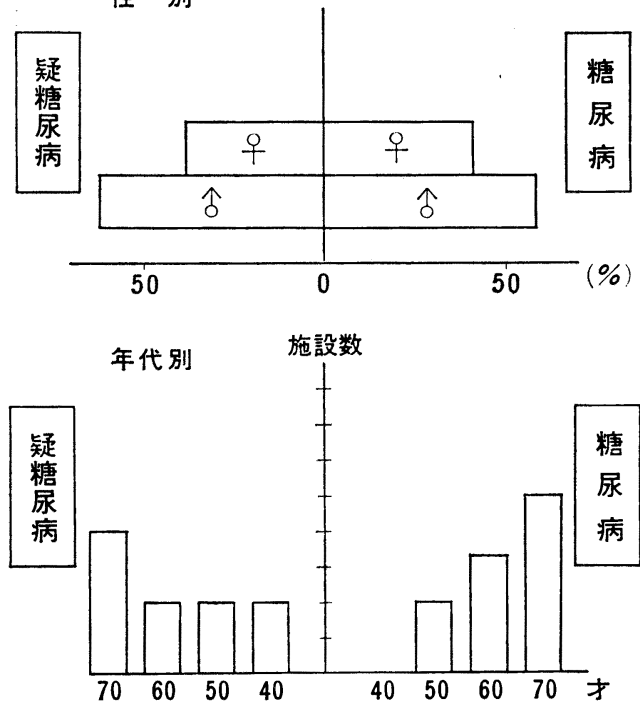

図No. 16 特 徵（集団検診）

“未知、既知比
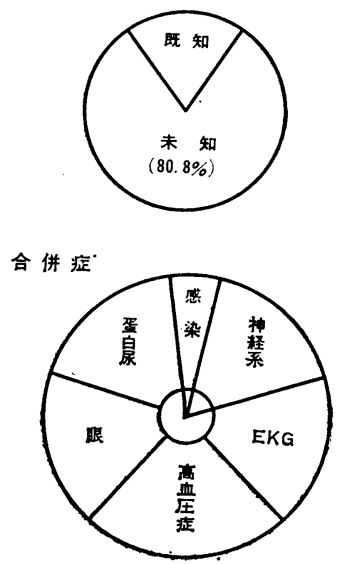

いといえる。

(3) 農村におりる糖尿病は，性別，年代別，合併症に おいてる，糖尿病研究班の調查成績に匹敵する病 態を示しているといえる。

\section{(2)私どもの行なった疫学的調査} 並びに臨床的覾察

\section{(i ) 外来・入院息者統計}

次に以上のアンケート調査成繥と, 私どもの病院にお ける統計について比較する。

その前に，私どあの病院の所在地を図示する（四No. 17)。私どもの病院は名古屋市より北へ約 $20 \mathrm{~km}$ ，木曽川 の南, 濃尾平野の北部に位置する江南市に所在する。

図No. 17 愛北病院所在地

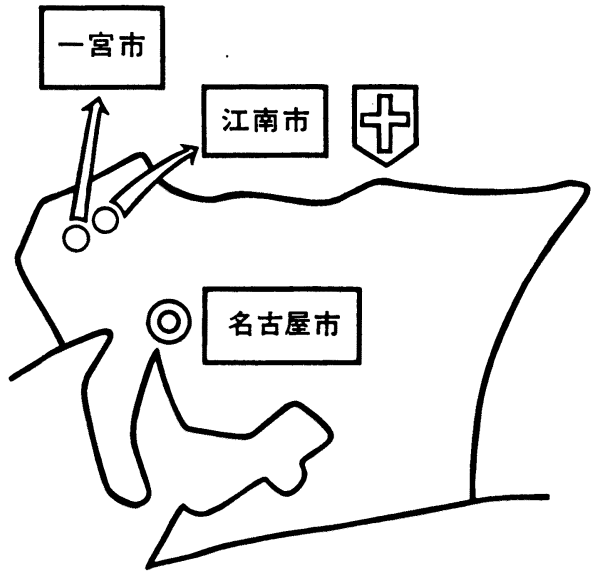

\section{愛 知 県}

江南市は人口約 6 万 4 千人，農家戸数 3,300 戸，うち 兼業農家は約89\%で，一戸当りの耕地は平均40アール過 去は畑作を主体とした農業地帯であったが，最近は内陸 工業地帯に変貌しつつある典型的な，近郊農村である。

従って当院における受部者の職業別分布は非農家が多 数を占めている。

こうした背景のもとに，当院内科における「外来及び 入院患者」について，糖尿病罹病率をみると（図No. $18)$, 昭和 30 年 1 月より 38 年 2 月までの 8 年 2 ケ月間に おける羅病率は患者総数付対し0.34\%と，極めて僅少で ある。しかるに昭和 40 年 4 月より 41 年 3 月までの 1 ケ年 間における糖尿病䍜病率は $2.7 \%$ と，約 8 倍に上昇を来 している。ての事実は勿論糖尿病そのものの増加もあろ うが，一面検尿回数の増加，糖尿病に対する医師及び患 
者の関心の増大など，発見動機のふえて来たてとあまた 見逃がせない点であろう。糖尿病のこうした発見率の上 昇は，今後の管理，合併症対策上きわめて重要ではある が, 反面との地方における糖尿病の推定には無理と思わ れる。

ひるがえって「外来及び入院患者の病態」に関する詳 細については，既に第11回本学会より 5 回にわたって報 告致したのでこてでは省略するが，ただ「死因別統計」 についてのみ触れてみたい（図No. 19)。

図No. 18 外来・入院患者統計羅病率

(昭 30.1. 38.2.)

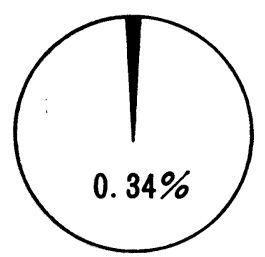

（対患者総数）

（昭 40.4. ～41.3.)

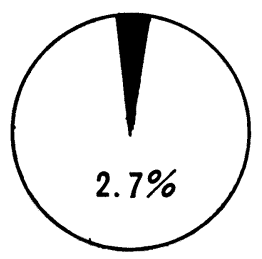

図No.19 外来・入院患者統計 死因別（昭30. $1 \sim 41.3$ )

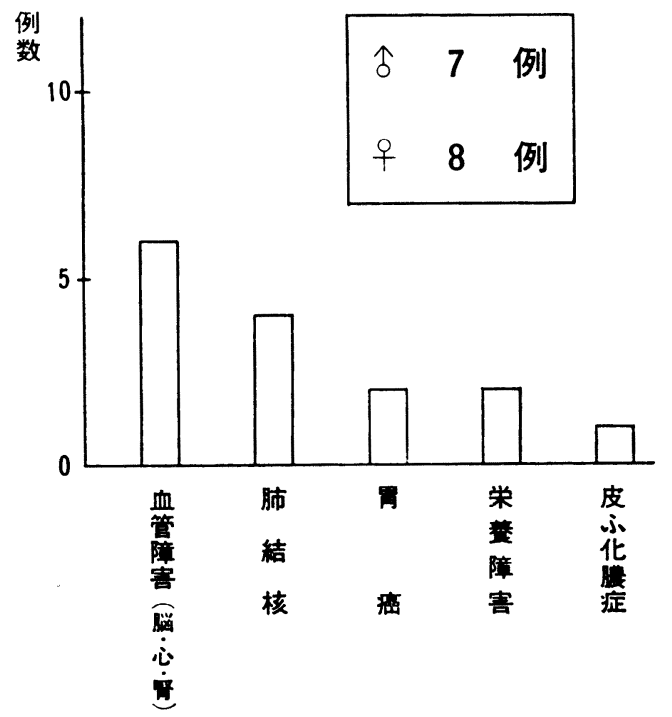

昭和 30 年 1 月より 41 年 3 月に至る期間の糖尿病死亡者 は15例で, うち男 7 , 女 8 例とほば同数である。その死 因は脳卒中, 心臓病, 腎臟病など血管障害が最も多く, ついで肺結核, 胃癌, 栄養障害の順である。ととにも糖 尿病と血管障害との結びつきが浮彫となっている。

以上外来及び入院患者における成績は，「アンケート 調査のそれと大差を認めない」といって差支えないと思 われる。

\section{(ii）人間ドック統計}

次に昭和 34 年 6 月より本年 6 月に至る 7 年間の「当院 人間ドックにおける糖尿病発見率」について申し述べ る。

当院人間ドックは， 2 泊 3 日のコースであり，現在ま で 212名の受診をみているが, このうち糖尿病は, 飽食 試験によったが，罹病率は10.1\%である（図No. 20）。

当院外来及び入院患者統計と比較して，その発見率は 極めて高い。また「男女比」も，男性の発見率 $10.5 \%$ 之, 女性を凌駕している (図No. 20)。「未知患者」あ告 強を示している（図No. 21）。

ここで注目致したいのは，人間ドックにおける糖尿病 者は，末知患者が多いのにもかかわらず，その「重症， 軽症の別」では (図No. 21), かなり重症者が多いとい うことである。古典的な糖尿病症候群を発する前に，糖 代謝の異常ないしは合併症が進展しているということの 証拠といえるであろう。

図No. 20 人間ドック統計

\section{発見率}

(昭34. $6 \sim 41.6$.
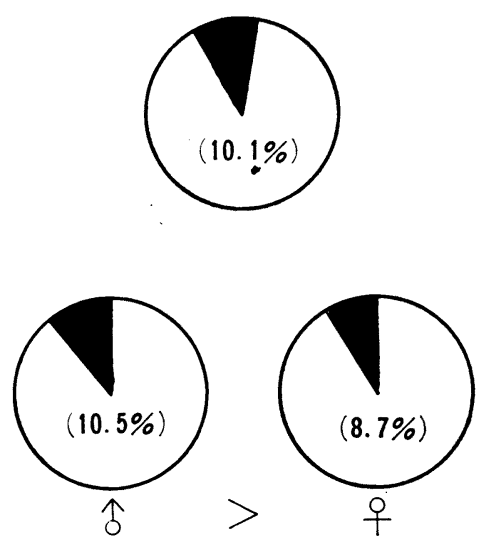
図No. 21 人間ドック統計

未知. 既知比

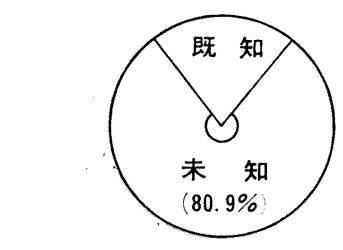

軽重度

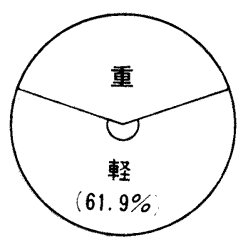

以上人間ドックの成績よりいえることは，「糖負荷試 験は糖尿病早期発見に不可決の条件」であるというとと に尽きるといえる。

\section{（iii）集団検誩成績}

次に集団検晾成績について申し述べる。

私どもが集団検診を行なった地域は（図No. 22），愛 知県尾張部のうち, 江南市布琶, 一宮市丹陽, 犬山市池 野, 丹羽郡替桑町及び海部郡鍋田干拓の 5 地域である。

こてで私どあは農村を笠原氏に従って, 次の 5 つに分 類した（図No. 23)。

即ち農業以外の人口が60\%以上を占める地域を「都市 的農村」, 水田が耕地面積の80\%只上を「田作地帯」, 水 田が耕地面積の50ないし80\%を「田作兼畑作地带」, 水 田が50\%以下の地域を「畑作地带」, 果物, 野菜, 養亘 などに依存することの大きい地域を「特産地帯」と分類 した。

あち万ん農村は（農個人の集団）に(非農個人の集団) をプラスしたものに，(地域）を乗じたものと考えられ る。即ち農村における糖尿病の実態む, 農, 非農 (個 人), 及びその (集団) ならびに種々の環境で構成されて いる(地域) についての比較検討が必要であろう。こう した観点から私どもは先に述べた地域を選定したわけで ある。

即ち, 布袋地区は「都市的農村」, 鍋田は「田作地 帯」, 扶桑及び池野は「田作兼畑作地帯」, 丹陽は「畑作 地帯」の典型的なむのである。さらに対照として布袋地 区の一工場を選んだ。この工場の従業員は, 北陸, 東北 の若き農家出身者で構成され, 地元出身者はごく僅かと いう特殊な集団である（表No. 6)。

次にてれら地域の「地形」をみると, 鍋田干拓は海抜
図No. 22 集団検診対象地域

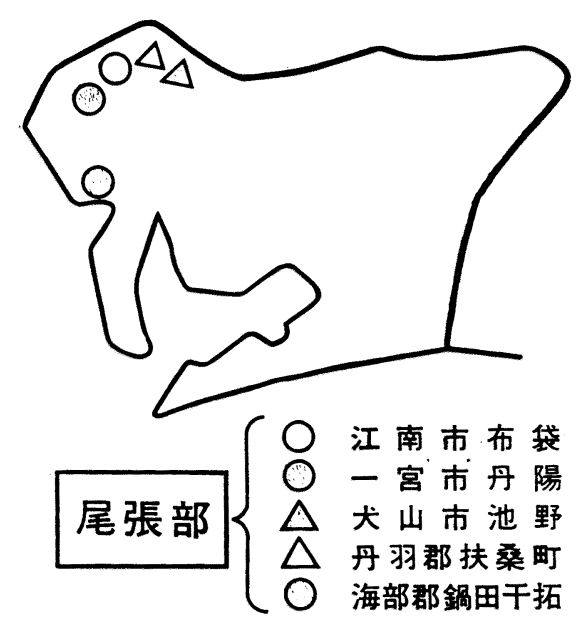

図No. 23 農村分類（笠原）

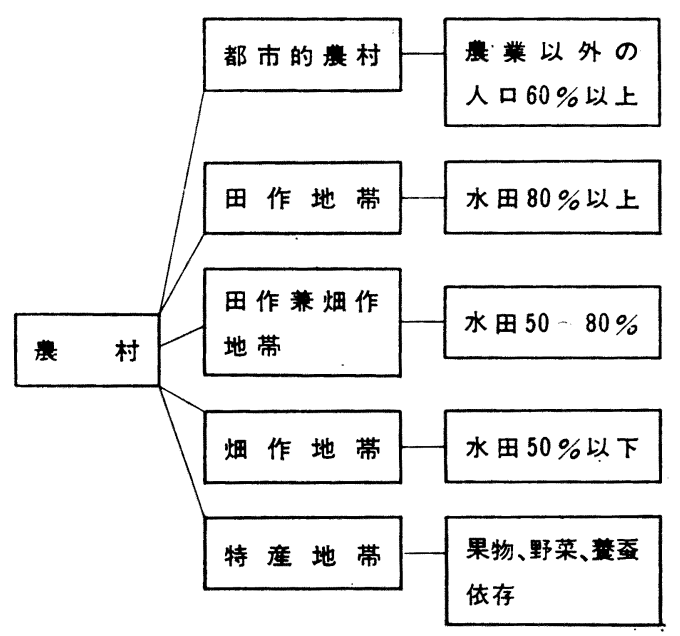

$0 \mathrm{~m}$ の低地, 池野地区はやや高地, 他はすべて平坦地で ある。

「受猃人員」は，対象の工場従業員を含好て，男 867 名, 女 1,016 名, 計 1,883 名,「検診実施期間」は昭和 39 年 3 月より本年 3 月までの 2 ケ年間である（表No. 6)。

次に「受診者の職業別構成」は，対照在除いたものむ 図示すると次の如くなる（図No. 24）。

即ち農家は71\%，非農家は29\%を示している。

次に私どもの「集団検彭方法」は，ほぼ糖尿病研究斑 の方法之同一であるが，ただ二次検査で，飽食後，血 糖，尿糖之も $1,2 ， 3$ 時間にわたり 測定した（四No. 25)。乙机は最高血糖优, 糖排出閾在観察するたるで古 
る。ざらに「判定方法」では, 空腹時血糖値が $140 \mathrm{mg}$ ， dl 以上, 2 時間後の泳粕陽性をむ「糖尿病」之判定し た。

なお血糖は Hagedorn-Jensen氏法, 耳染より採血し, 尿緯は Tes-Tape 法によった。

次に糖尿病研究班の飽食試験における「糖負荷量」

表No. 6 瑟検検查対象

\begin{tabular}{|c|c|c|c|c|c|c|c|}
\hline 地 域 & 耕地 & 地形 & $\begin{array}{l}\text { 対象 } \\
\text { 年令 } \\
\end{array}$ & $\hat{0}$ & 우 & 計 & 年月 \\
\hline 布 袋 & $\begin{array}{c}\text { 都市 } \\
\text { 的 }\end{array}$ & 平担 & $20>$ & 427 & 609 & 1034 & $\begin{array}{c}39 \\
\dot{3} \\
\downarrow \\
10\end{array}$ \\
\hline 扶 桑 & $\begin{array}{l}\text { 田 } \\
\text { 畑 }\end{array}$ & 平担 & $35>$ & 125 & 155 & 280 & $\begin{array}{c}40 \\
\dot{3} \\
\downarrow \\
5 \\
\end{array}$ \\
\hline 鍋 田 & 田 & 低地 & $|30\rangle$ & 70 & 33 & 103 & $\stackrel{40}{\dot{7}}$ \\
\hline 池 野 & $\begin{array}{l}\text { 田 } \\
\text { 㚼 }\end{array}$ & 高地 & $20>$ & 88 & 88 & 176 & $\begin{array}{c}40 \\
\dot{9} \\
\downarrow \\
10 \\
\end{array}$ \\
\hline 丹 陽 & 畑 & 平担 & $30>$ & 31 & 1119 & 150 & $\begin{array}{l}40 \\
11\end{array}$ \\
\hline \multirow[t]{2}{*}{ 布 袋 } & 工婸 & & 25> & 126 & 14 & 140 & $\begin{array}{c}41 \\
\dot{3}\end{array}$ \\
\hline & & & & 867 & 1016 & 1883 & \\
\hline
\end{tabular}

図NO. 24 集検受診者 職業別分布

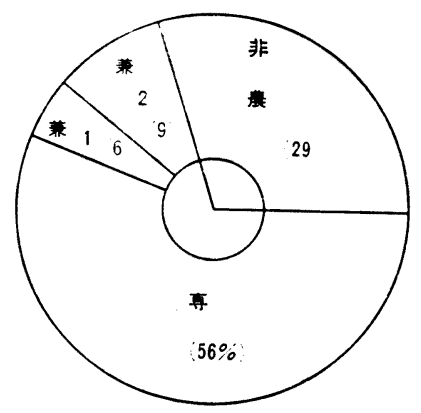

は「「米飯 $300 \mathrm{~g}$ 以上，場合によっては甘い菓子を加え る!となっており， この最大量に対する基準はきめられ ていない。しかるに農民においては食生活のうち，とく に米の過食という問題が存在する。

私どあは目下集団検診に際し，米飯 $400 \mathrm{~g}$ を摂取させ
図No. 25 検 查 方 法

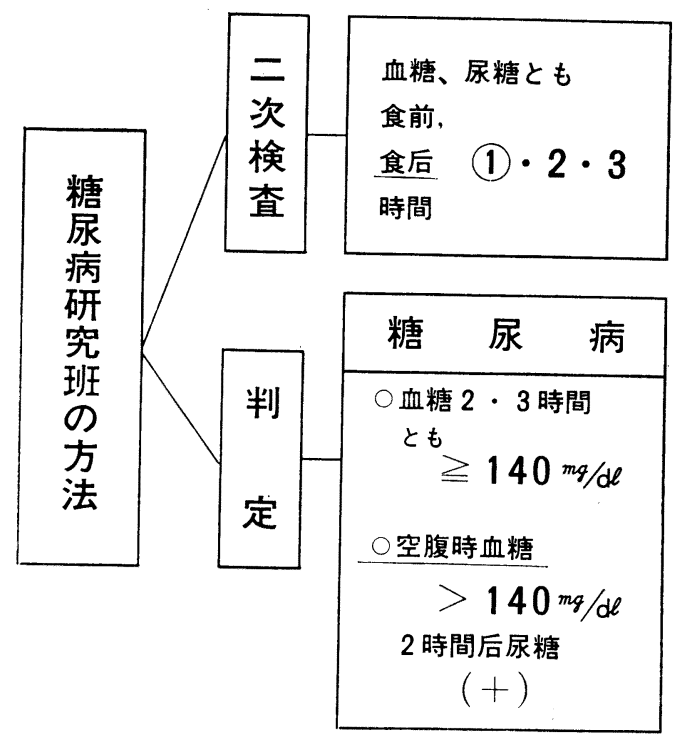

ているが，てれは（図No. 26）に例示した如く，成人男 子に米飯 $400 \mathrm{~g} ， 500 \mathrm{~g}$ を与えた場合，食後 2.3 時間之 むに血糖曲線に著変を認めていないととによりかくの如 き負荷量を用いているわけである。

さて，かかる方法で「発見された糖尿病」は（図No. 27）の如 $く$, 検查対象の $4.87 \%$, 疑糖尿病は $1.54 \%$ 之い う結果を示したのである。先に述べたアンケート調査 で，農村に限定した際の糖尿病発見率3.3から5.5\%, 疑 糖尿病 3 から $5.3 \%$ と比較して, 疑糖尿病はやや低率で はあるが，糖尿病は極めて近似の成績である。勿論糖尿 病, 疑糖尿病とも「男性」が優位を示すが, 疑糖尿病で は男女ほぼ同率の発見率である（図No. 27）。

上述の発見率は受診者全員についてであるが。てれを 「各地域別」にみると(罒No. 28), 糖尿病では鍋 田 $2.98 \%$ ，丹陽 $3.33 \%$ ，扶桑 $4.33 \% ，$ 池野 $4.67 \%$ ，布袋 $5.9 \%$ という成績で，一方疑糖尿病は丹陽 $4.44 \%$, 池野 $2.67 \%$ ，布袋1.84\%で，その他の地域では疑糖尿病を認 めなかったのである。なお対象の工場では糖尿病のみ $0.81 \%$ と，その発見率は極めて低率であった。

さててれらの成績は，対象年令が各地域不同である関 係上，てれを「40才以上の男女」について観察すると （図No. 29），糖尿病は布袋 $7.26 \%$ を最高に，鍋田 3.33 \%を最低とする発見率で，勿論各地域とも，年代と共に 発見率の増加を認めるのである。なお疑糖尿病は池野, 布袋地区では受診者全員に対する発見率より増加を認め るが，逆に丹陽地区では疑糖尿病の減少がみられるので 


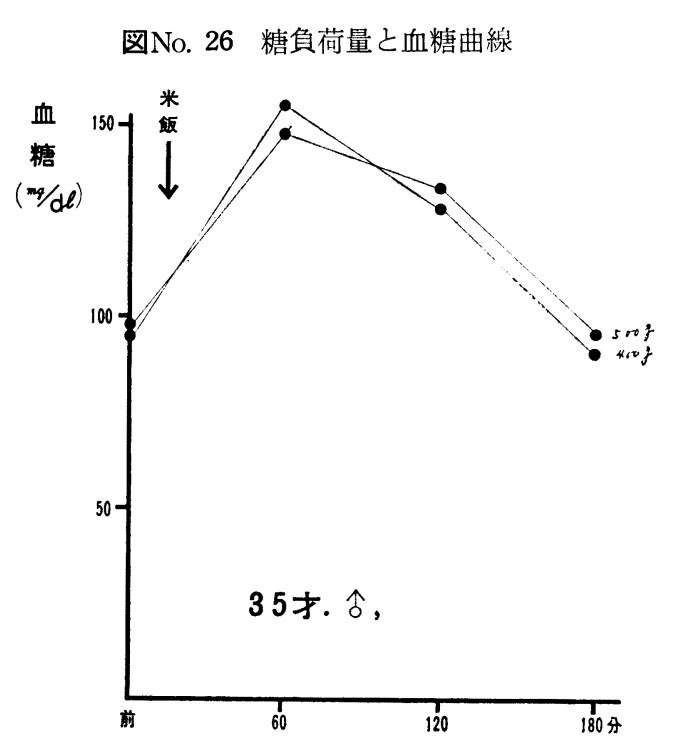

図No. 27 集検発見率及び性別分布
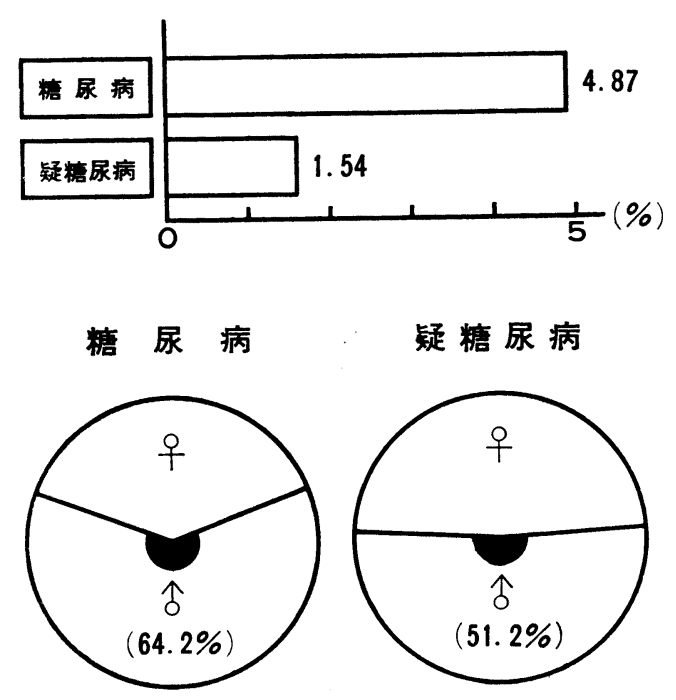

図No. 28 集検発見率地域別

(地域別)

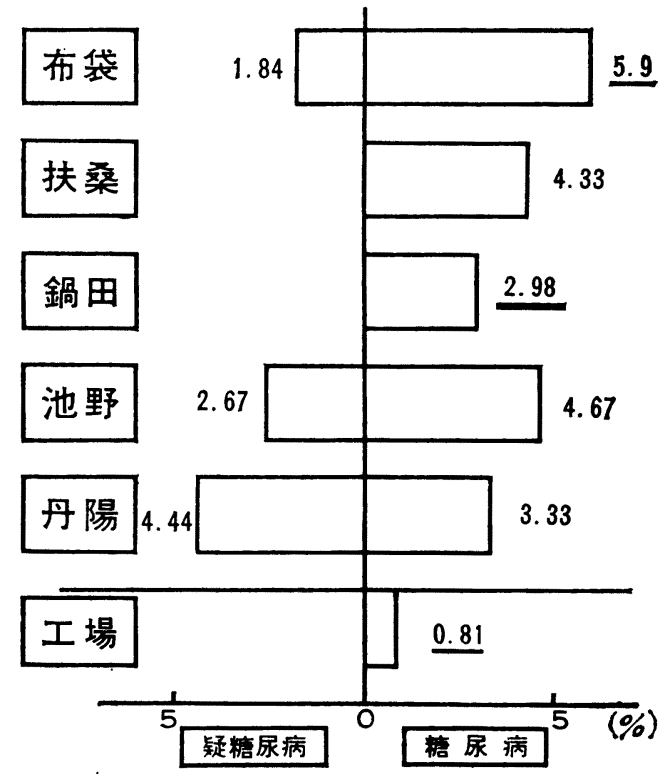

図No. 29 集検発見率（40才以上）

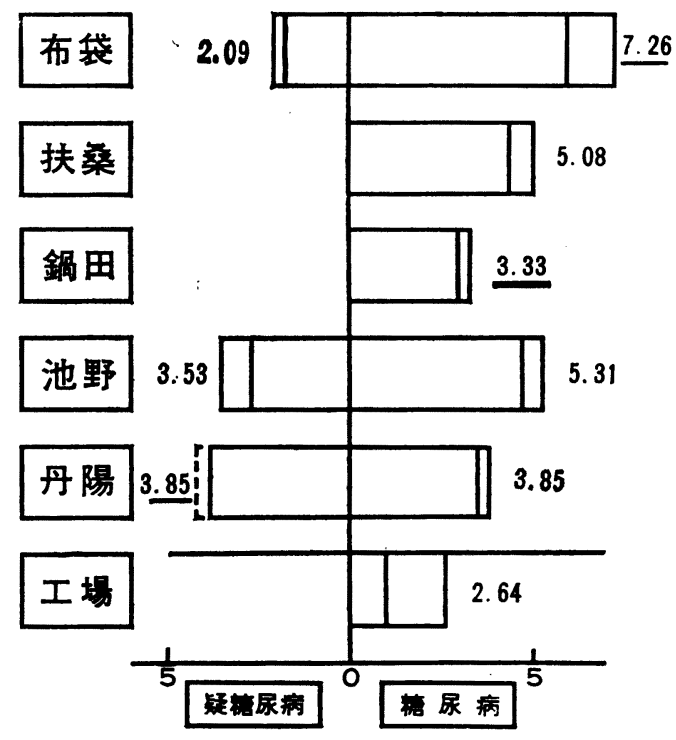

あって，ての地区では40才以下に疑梙尿病が多いここを 示している。

一方対照工場においては 40 才以上では糖尿病 $2.64 \%$ と 著しい増加を来し, 反面若年者層に榶尿病が少いという ことを示している。

以上の成績が示す如く，農村を便宜上 5 つに分類して 
分析した際，「都门的農村」である布袋地区において最 高,「田作地带」で若き移植者の多い鍋田地区で最低, その間に「田作兼畑作地带」である扶桑，池野地区がほ ぼ同率でならび，ついで「畑作地带」である丹陽地区が つづくという結果が示されたわけで，ての結果をあって 軽々しく速断は出来ないが，糖疗病の発症要因を考える 場合，興味ある点といえる。

即ち農村の都市化, 人口の老令化に関連ある結果之考 えられるのである。

次に発見した糖尿病者の「年代别分布」であるが，糖 疗病は $60 ， 40 ， 50$ 才の順，一方疑糖尿病は60，50，40才 代の順で, やはり成人層で增加を示している（図No. 30)。

また「既知, 未知患者比」は,末知が87\%と, 圧倒的 に多い成績で，ここにも実態調查の重要性が示唆されて いるのである（戝No. 31）。

次にこれら糖尿病者の「職業别分有」をみると（図 No. 31), 専業農家 $66 \%$ ，兼業 1 種 $6 \%$ ，兼業 2 種 $9 \%$, 計農家 $81 \%$ ，非農家19\%宁で，農家の糖氺病の方が多数を

図No. 30 年 代別 分 布 (集検)
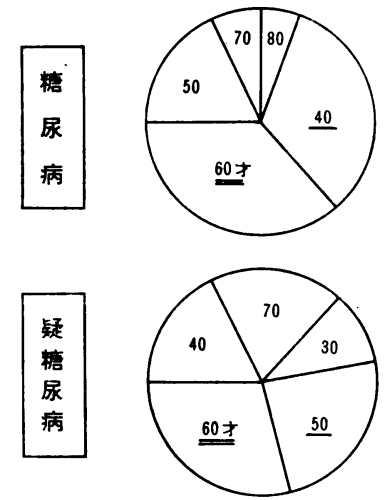

占め,これを先に述べた受款者の職業別分布（図No.

24）之比較すると，専業農家において発見率が最す高

く，非農家において最も低い結果となっている。

次に発見糖尿病者の病態について少しく観祭致した W。

第一に「軽症, 重症」の問題であるが, 現在糖㽷病の 軽症・重症を定義するには, 代謝面, 治療面などより分 類されているが, なお一定の基準はない様である。ここ では（表No. 7）に示す如く，「上田教授の分類法」に従 い, 糖负荷後 2. 3 時問の血糖值が双方とも $160 \mathrm{mg} / \mathrm{dl}$ 以下を $\mathrm{D}_{\mathrm{I}}$ ，双方が $200 \mathrm{mg} / \mathrm{dl}$ 以下で，その一方が 160 $\mathrm{mg} / \mathrm{dl}$ 以上を $\mathrm{D}_{\mathrm{II}}$, 一方が $200 \mathrm{mg} / \mathrm{dl}$ 以上を $\mathrm{D}_{\mathrm{III}}$ とし, $\mathrm{D}_{\mathrm{I}}$ は経過を観察し，定期的に検罡を行うむの， $\mathrm{D}_{\mathrm{II}}, \mathrm{D}_{\mathrm{III}}$ は
治療を要するものとする。

また従来分類されて来た「空腹時血糖值」 $[140 \mathrm{mg} / \mathrm{dl}$ 以下を I， 140 から $200 \mathrm{mg} / \mathrm{dl}$ をII，200 $\mathrm{mg} / \mathrm{dl}$ 以上をIII として観察すると，「男性」では（図No. 32）に示す如 く, $\mathrm{D}_{\mathrm{I}}$ が42, と最む多く，ついで $\mathrm{D}_{\mathrm{II}}, \mathrm{D}_{\mathrm{III}}$ の順で, 一 方空腹時血糖值もIが92\% と圧倒的で，IIIは全く認めら

図No. 31 既知・未知比（糖尿病）

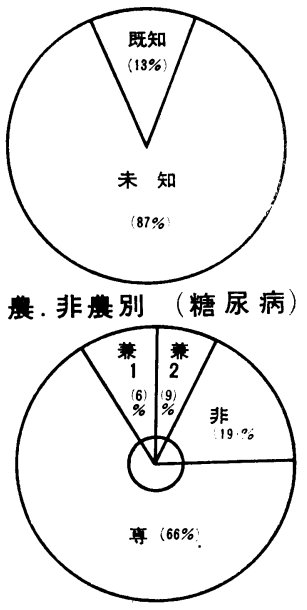

れない。しかるに「女性」では $\mathrm{D}_{\text {II }}$ が鼠も多く, 479 示し, 逆に $D_{I}$ は $16 \%$ と最も少く, 空腹時血糖値も I は 男に比し低率で，むしろ II及び而が増加を示している。

さきに私どもが第 2 報において報告した「農村におけ る糖尿病は, 女性に重症例が多い」という報告と, 全く 一致する結果を得たのである。

次に発見した糖㽷病者の「体型」を観察すると（図 No. 33)，肥満者に糖尿病が多いという脂質代謝との関 連が強調されているが, 私どもの成績によると, 糖㽷病 ではむしろ中間型が過半数を示している。しかるに疑糖 疗病では肥満型が47\%を占め, 糖㽷病発症要因のうち, 肥満との関連を物語っている。かかる体型の分布もま た, 農村における糖㽷病の病態の一面を示す如くに思わ れる。

しからば先天的素因である「遺伝因子」との関連につ いて観察すると（図No. 33），遺伝を有するものは6\% で，かなり低率である。

糖尿病が社会各階層に浸潤しつつあることは今迄の成 績が示す如く，現実の姿ではあるが，かかる成績の中に は遺伝因子は勿論であるけれどあ，一面他の後天的要因 の比重の増大が農村においても予想される如くであり， 注目すべきことと思われる。

ひるがえって，糖㽷病の「合併症」は，患者の予後を 
図No. 7 糖尿病軽重度判定

\begin{tabular}{|c|c|c|c|c|}
\hline & \multicolumn{3}{|c|}{ 糖負荷后 $2 \cdot 3$ 時間血糖値 } & \\
\hline L & 双 & 方 & $<160 \mathrm{mg} / \mathrm{d} \ell$ & $\begin{array}{l}\text { 経 } \\
\text { 過 }\end{array}$ \\
\hline iI & 双 & $\begin{array}{l}\text { 方 } \\
\text { 方 }\end{array}$ & $\begin{array}{l}<200 \mathrm{mg} / \mathrm{d} \ell \\
>160 \mathrm{mg} / \mathrm{d} \ell\end{array}$ & 治 \\
\hline $\mathbf{D}_{\mathrm{H}}$ & - & 方 & $>200 \mathrm{mg} / \mathrm{dl}$ & 療 \\
\hline
\end{tabular}

(上田)

\section{空腹時血糖值}

空腹時血糖值

I. $140 \mathrm{mg} / \mathrm{dl}$ 以下

II. $140 \sim 200 \mathrm{mg} / \mathrm{dl}$

III. $200 \mathrm{mg} / \mathrm{dl}$ 以上

図No. 32 軽 重 度 (集 梚)
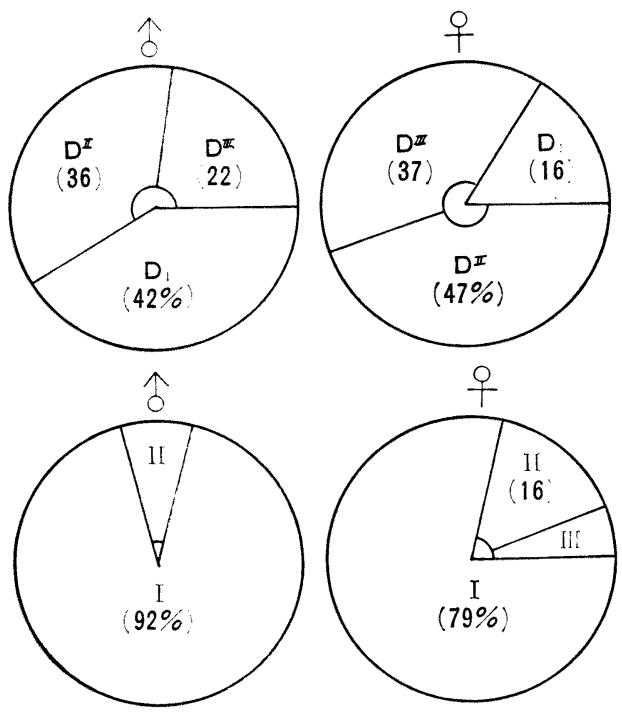

決定する重大な要素である。とくに血管障害との関連は 無視出来ない。集団検診で発見された糖尿病者について 観察すると，（図No. 34）の如く, 高血圧, 蛋白尿, 網 膜症, 増窒素血症, 脂血症などの発見率は極めて高い。 しかも未知発見患者が多いにもかかわらず，血管障害の かなり進展している例が多いという事実は，糖㽷病早期 発見の重要性を物語るあのといえる。とくに軽症が多い 「男性側にかかる傾向の強いこと」は，私どもが既に第 2 報において報告した成績と合致する。
図No. 33 粒尿病体型分類（集 椮）

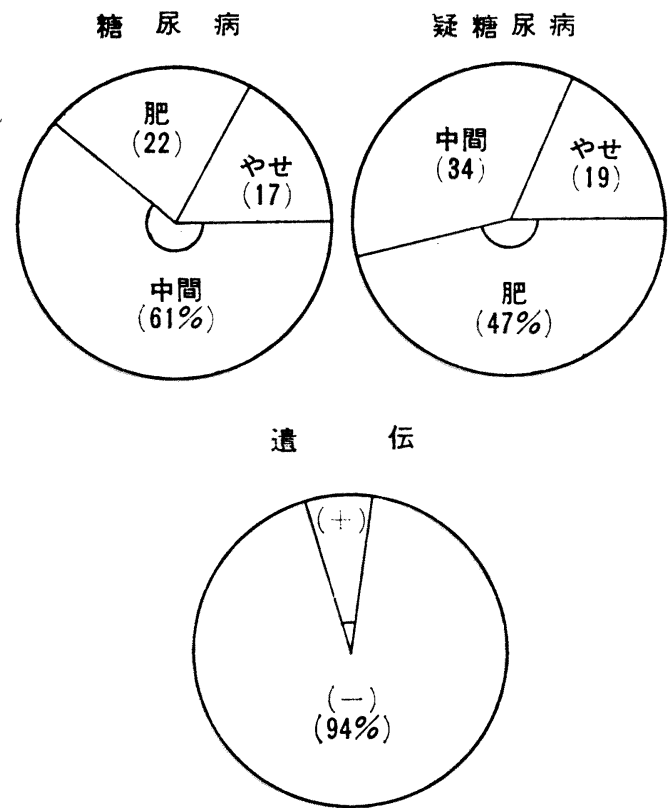

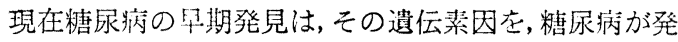
将する前に発見することであるといわれているがこのた めには特に糖尿病性細小血管症 (mikro angiopathie), 即ち細小血管の変化に着目しなければならない時代とな っている。今後代謝面の追究と共に，こうした方面への 検索が極めて大切であることを物語るむのである。なお 農民にみられる腰痛症などの神経障芯には，糖㽷病が潜 在する場合があるということも，合併症よりみて考慮に 入れるべきであろう。

次に集団検診で発見された糖尿病及び疑糖尿病が，あ る年月ののち，「如何なる経過」を辿るかを観察する (図No. 35)。

糖尿病として明確に診断を下し得る例は別として，今 日最も問題となるのは, 非糖尿病との境界にあるborder lineの例である。

かかる例は病態観察によって，その管理方法をきめて ゆくより他ないであろう。

私よ゙もの成績では当初糖尿病と診断した 20例につい て，半年ないし 1 年後, 飽食試験を行ってみると, 治療中 にもかかわらず，その19例は血糖曲線に著変を認めなか った。しかるに疑糖尿病は15例より10例に減少，非糖尿 病性糖尿は 8 例より 6 例に減少, 逆に非糖尿病が 8 例あ らわれている。この事実は border line の例における診 断基準が，今後早急に確定されることの望まれるゆえん であり，同時にかかる例の管理の重要性を物語るもので 
図No. 34 糖尿病合併症（集検）

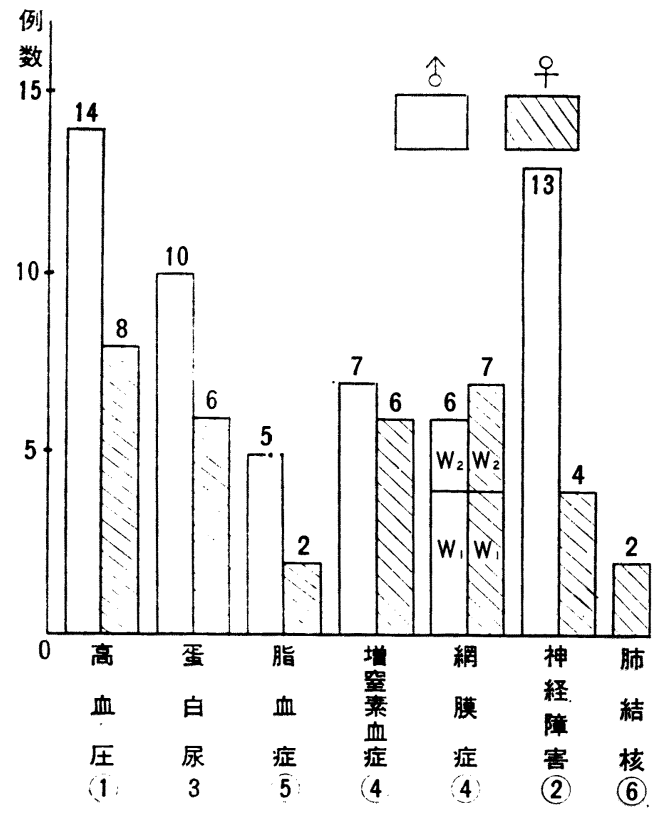

図No. 35 経 時 観 察 (集 検)

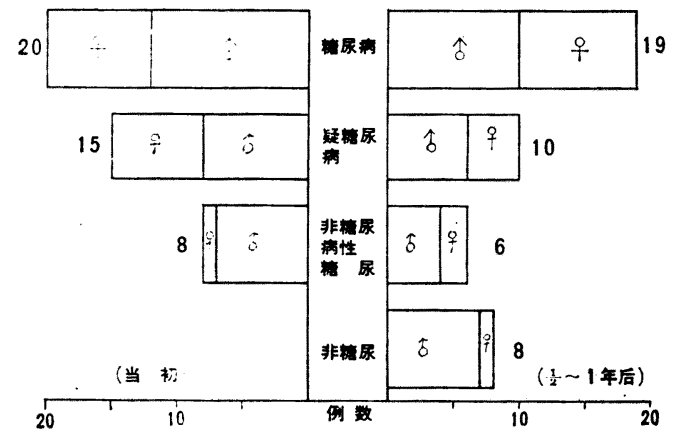

ある。

次に発症要因のうち, 「生活環境とくに食生活」との 関連について触れてみたい。

糖尿病は経済状態, 食糧事情を反映することが多いと されている。私どもは昭和 36 年度江南市五明, 昭和 40 年 度江南市小折において江南保健所の協力を得て, 生産者 世帯を主体として, 国民栄養調査方式により栄養調查を 行った。

江南市五明での糖尿病発見率は $2.1 \%$, 江南市小折の これは496であるが，ての調査で注目致したいのは（図 No. 36，37）に示す如く, 時点の差はあるが, Vitamin $\mathrm{B}_{1}$, Vitamin $\mathrm{B}_{2}, \mathrm{Ca}$ の摂取の甚だ少いことである。 しかしながら基準量と比較して, 米の過食はむしろ見当 らない。即ち在来の農村における栄養調査成績とも比較
して，糖尿病発症上着目すべき問題点に欠りる如く思わ れる。けだし糖尿病発症因子の複雑多岐なるととの一例 とあ考えられる。

さらに私どもは，乙の検診で 2 組の「夫婦糖尿病」を 発見した。生活環境, 各種ストレスなどに共通点を多く むった夫婦にみられる糖泳病の病態は, 発症要因をさぐ るのに恰好の材料である。こてには一組の例について例

図No. 36 栄養調 查 (その1) （国民栄養調查方式による）

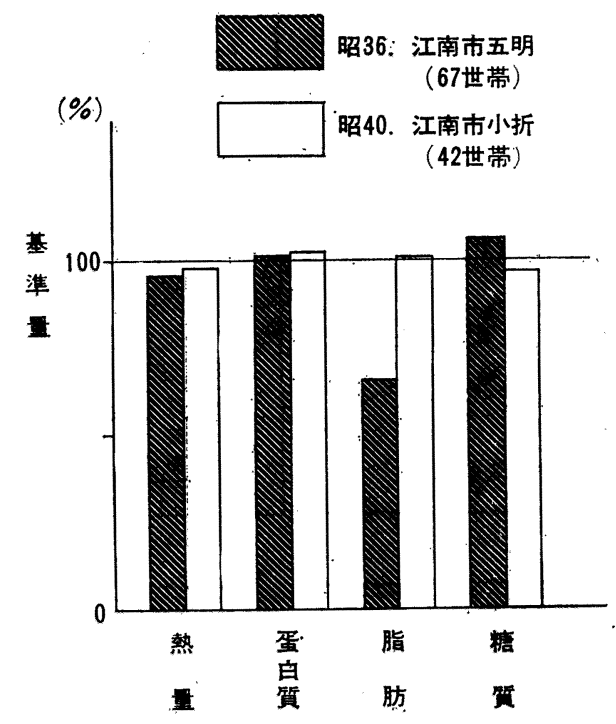

図No. 37 栄 養 調 查 (その 2$)$

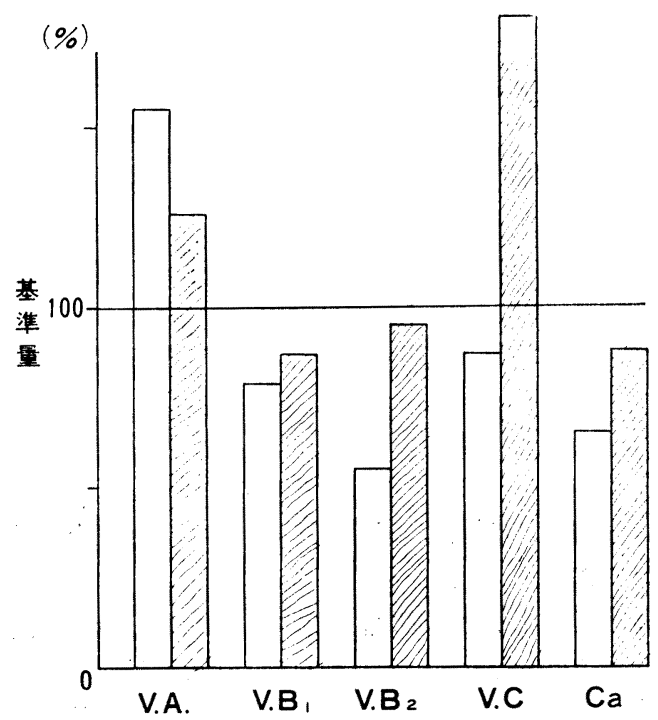


示する（図No. 38）。この夫婦は専業農家で，体型は中 間型に属し, 夫は当初糖尿病, 1 年 9 ケ月後非糖尿病, 妻は当初疑糖尿病, 1 年 9 ケ月後は非糖尿病性糖尿を示 し，夫婦とも食事指導のみを行った例である。けだし世 に云う「似た者夫婦」の好例である。

最後に集団検診によって発見した「糖尿病の治療」に

図No. 38 夫婦糖尿病（集検）

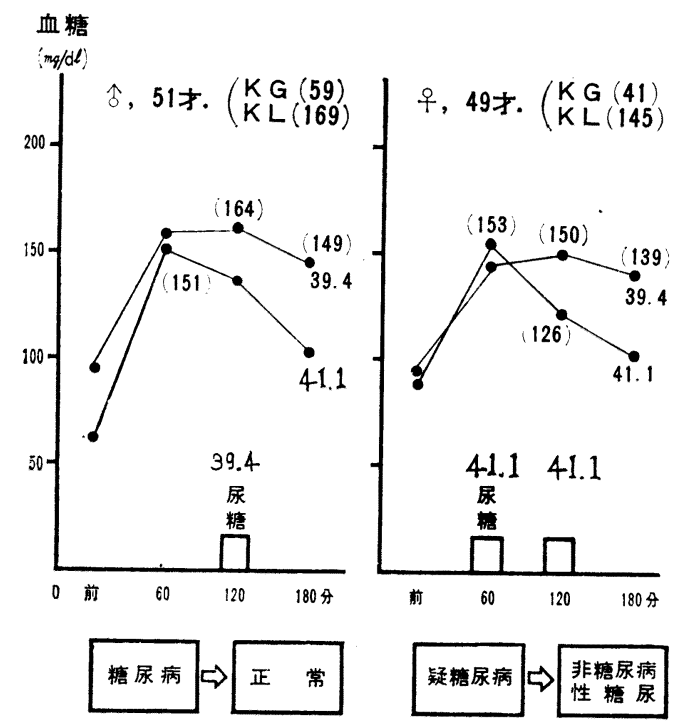

図No. 39 治療法（集 検）

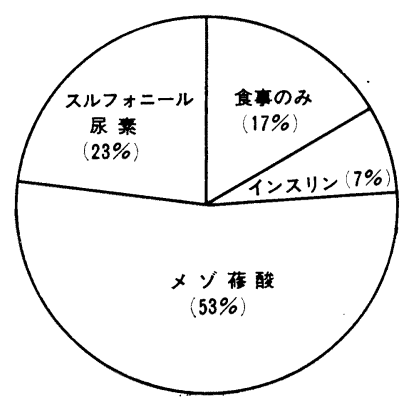

ついてであるが (図No. 39)，さきに病態観察でのべた 如く, 未知, 無自覚性, 軽症糖尿病者が多い関係上, 私 どあは主に「メゾ蓚酸」を使用し，ついで，「スルフォ ニール尿素」「インスリン」の順で Control した。勿論 全例食事指導を行っている。現在その大部分は, 当院に 受晾中であるが, Control 不良例はない如くである。
以上の集団検診成績をとりまとめてみると，

(1) 農村を種々の地域に分類して，集団検㐱を行い分 析を試みた結果, 地域別に変動はあるが, 少く上 も40才以上に限っていえば3.33\%から7.26\%のの糖

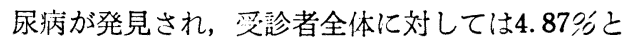
いう高率の発見率が得られた。

(2) 年代別では老年層，かつ男性に多く，一方未知患 者は87\%を占为，しかも農家では非農家に比し圧 倒的に発見率が多かった。

(3) 農村にお污糖尿病は，女性汇重症例が，また男 性では血管障害の比重が強いという, 私どもの過 去の報告と一致した。

(4) 経時観察の際, 疑糖尿焫, 非榶尿洺性糖尿例は当 初に比し減少し, 血糖曲線の正常となる例が多か った。

(5) 発症要因のうち, 遺伝, 食生活上の関連性は著明 でなく，一方年令との関速は藷明であった。さら に疑糖尿刻では肥満との関連が涊めら祅た，とい うことになるのである。

なお「蛋白及び脂潩代謝面」などに関しては, 別に判 告致しておるので，ここでは少略する。

\section{〔IV) 糖尿病早期粀}

\section{とくにスクリーニンク法について}

糖尿病の早期発見, 早期治痖が如何に二の人の一尘痘 左右するかは，今迄䎲し述べて来た成績によってあ明ら かである。しかも糖尿施は，その勆断に「血榶」という 手段が必要である。しかるに血糖検查は粠密な生化学的 操作を必要とする関係上, 検查する侧も, 梌査さ机る侧 む，かなりの時問之労力を必要とする。

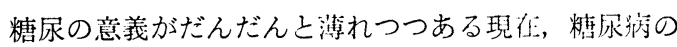
早期発見に対し，より簡単で，より適確な方法がない子 のか，農村の現实に立った埸合考えさせら杞万問題であ る。

こうした条件と相まって，集団検牾では「灾沴率」が

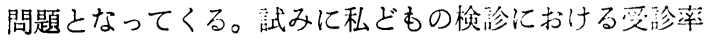
をみると (戝No. 40)，丹陽地区では100兄示すが，こ れは「農業者健康生活管理特別事業」実施地区のた引で

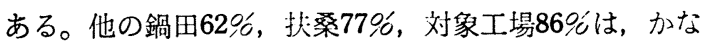
り良好の受㟝率であるが，強力なるPRにむかかわら ず，布袋，池野地区は30\%にすぎなかった。この事実は 健康管理に対する一般の関心の薄さを示すもの上いえ る。 
図No. 40 集団検㟝桑㟝率

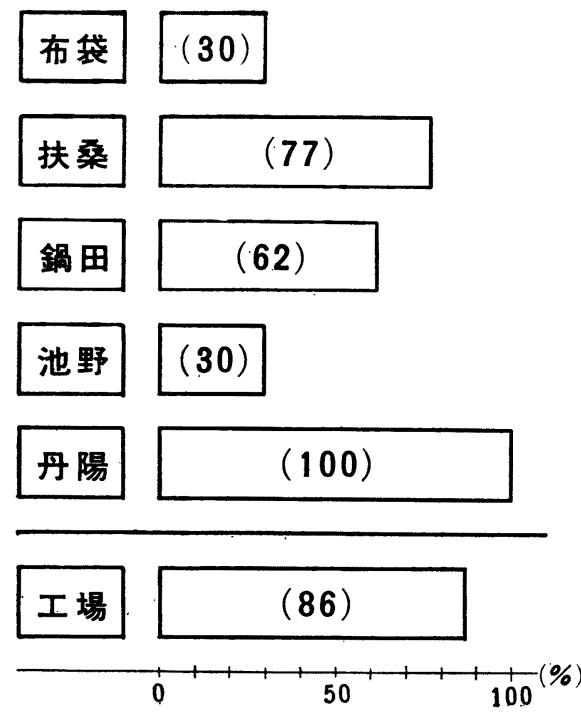

さて集忖検渗におけるスクリーニング法の簡易化に対 する試みとして，符一次検查において「血糖を除外する ことの可否」について次に検舎致したい。

「第一次検査異常者の比率」をみると, (図No. 41) に示す如く，血糖異常，尿糖正常の例が57.4\% c圧倒的 に多いのである。なお血糖正常・尿糖異常者は, $32.4 \%$, 血糖, 尿糖とも異常は. 10.2\%である。即ちスクリー二 ング法を尿糖のみで行うとすれば，落ちこぼれが極めて 大きいというととになる。しかも第一次検査異常者より の「糖尿病，疑糖尿病発見率」をみると（図No. 42）, 血糖正常, 尿糖異常の群からは31.6\%, 血糖異常, 尿糖 正常の群からは35\%，血糖，尿糖とも異常の群からは76 \%の発見率を得た。換言すれば血糖異常の群からは, 28 号の糖尿病, 疑糖尿病が発見されたのに反し，尿糖異常 の群からの発見率は18\%にすぎないのである。

この事実は，第一次検査において「血糖は除外できな い」ととを示すといえる。

しからば血糖を除外できないとすれば，最近利用度の 高まりつつある「簡易血糖法」で，精密血糖法の代用が 出来ないかという問題が提起されてくるのである。

私よ゙すは「比色定量試験紙」による方法で, 精密法と の比較を同時に試みた。なおこの方法は「真糖値」を示 すとされている。

その結果は（図No. 43）に示す如く，228 例の対象 についてみると, 一次検査異常者は「精密法」では血糖
$140 \mathrm{mg} / \mathrm{dl}$ 以上が $6.1 \%$ ，「簡易法」では $130 \mathrm{mg} / \mathrm{dl}$ 以上 が 9.7\%で，簡易法でひっかかる比率は精密法よりむし ろ大であるという成績であった。なお双方とも異常を示 す例は1.3宅にすぎなかった。

しかるにこうした第一次検査陽性者について, 今度は

図No. 41 スクリーング法（集検）

(糖尿病研究班の方法)(その 1)
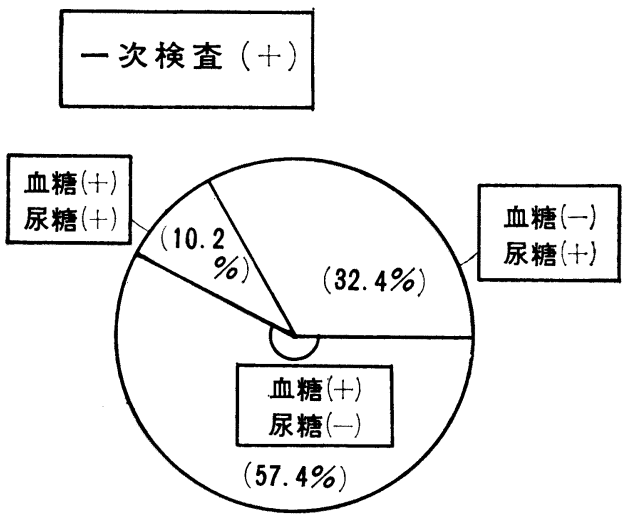

図No. 42 スクリーニング法 (集検)

(糖尿病研究班の方法) (その 2)

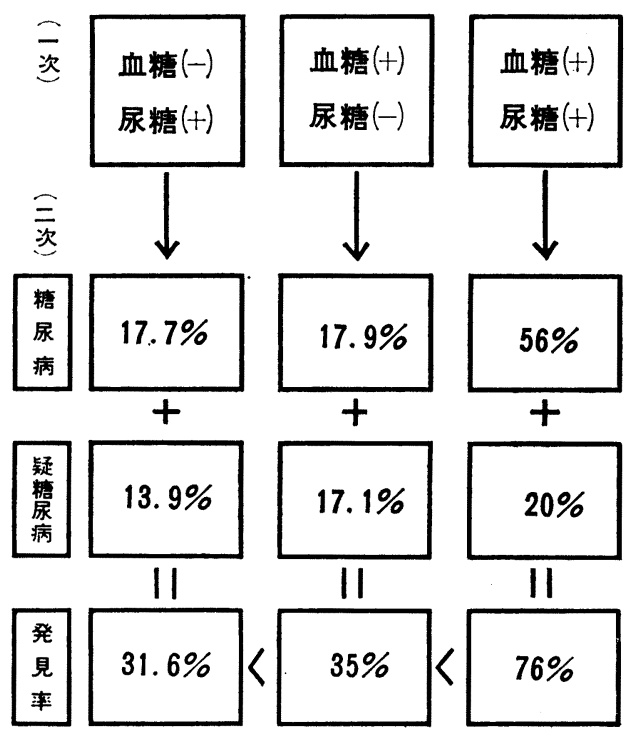

精密法を用い，飽食試験による「第二次検査」を行って みると（四No. 44）に示す如く，精密法14例からは, 糖尿病 1 例，疑糖尿病 2 例を発見したが，簡易法の 22 例 からは発見者0で, 一方精密法, 簡易法とも異常であっ た 3 例からは 1 例の糖尿病を発見した。 
図No.43スクリーニング 法 (集検) （簡易血糖法）（その 1）

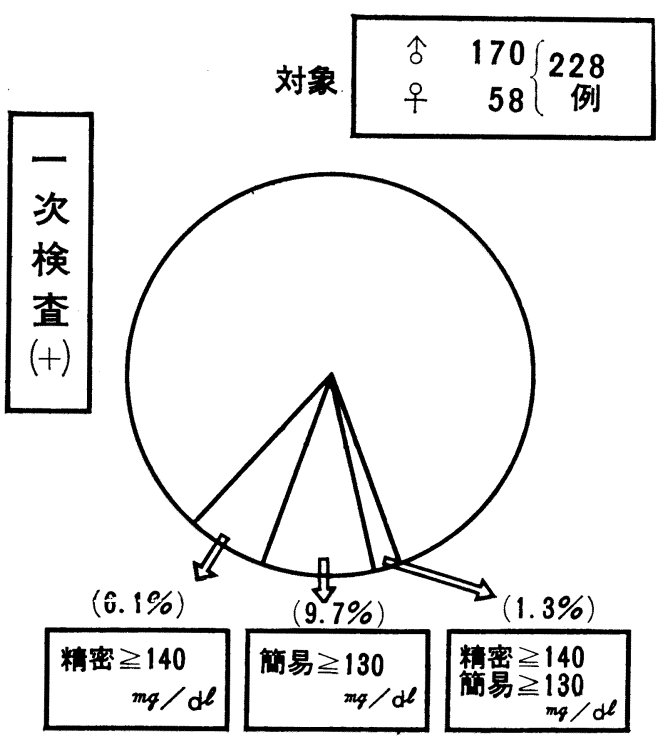

図No. 44 スクリーニング法 (集検)

(筬是血渃法)(天の2)

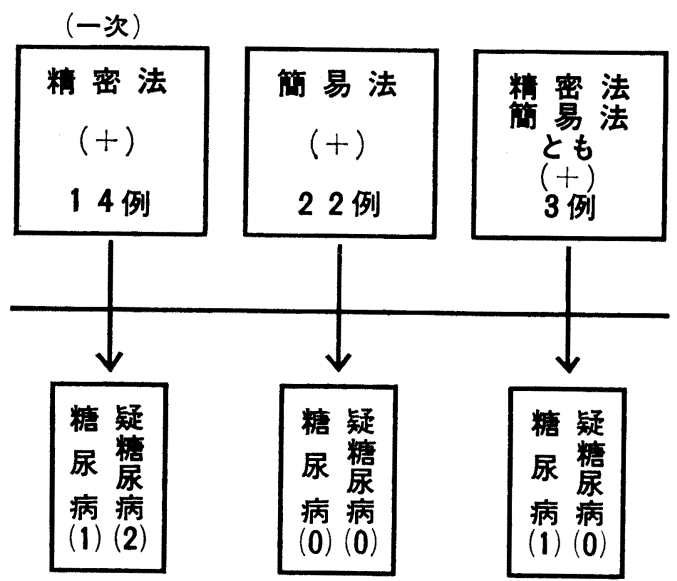

(三次)

以上の成績は「簡易血糖法」は手っとり早い方法では あるが，その判定にはかなりの熟練を必要とし，一次検 查でひっかける率は精密法に比し大ではあるが，第二次 検査での発見率は芳しくないという成績が示す如く，第 二次検査における労力を考えあわせる時，結局「簡易法 は救急時をのぞき, スクリーニング法としては労少くし て, 結果的には労多しという次善のあのにすぎない」と 思われる。

次に最近「皮ふ表面検査」によるスクリーニング法が

\section{図No. 45 スクリーニング法（皮腐表面法）}

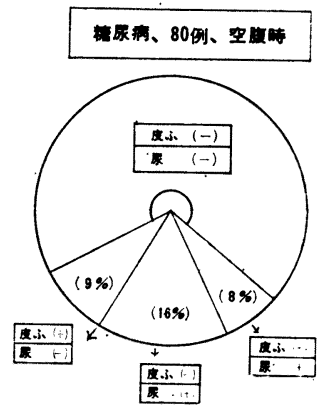

図No. 46 飽食試験, と皮鹿表面法 (この1)

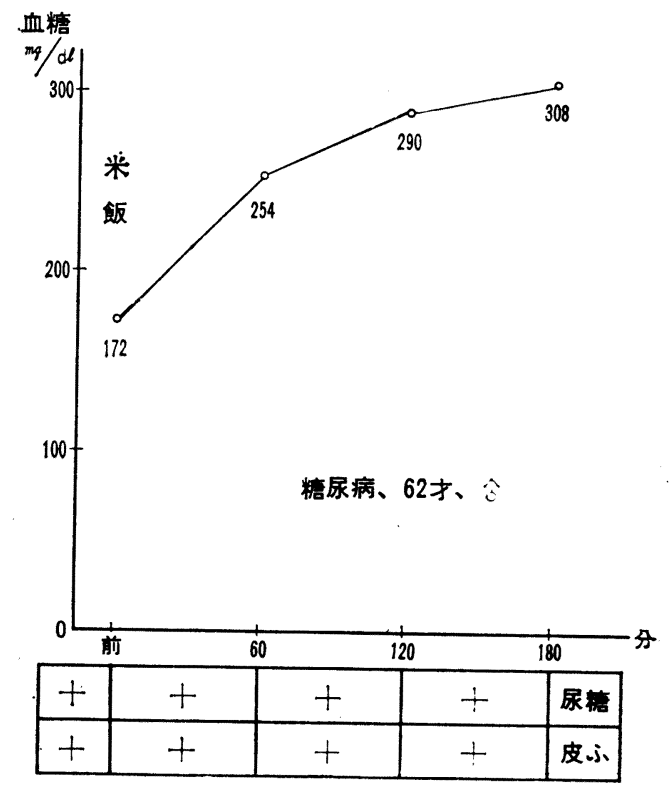

試みられているが，これは尿糖検査よりあ簡便であると いう利点のためである。

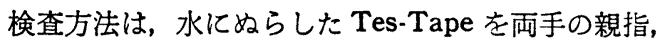
人差指の間に 1 分間はさみ, 変色の有無をみる方法であ る。

私どすは80例の糖尿病患者について, 空腹時, 血糖, 尿糖と同時に検索した。

その成績は（四No. 45）に示す如く，皮ふ陰性，尿糖 陽性は $16 \%$ ，皮ふ陽性，尿糖陰性は $9 \%$ ，双方之も陽性 は8\%で，他の67\%はいつれれ陰性であった。

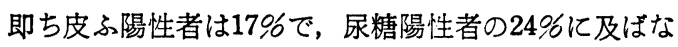
い。との皮ふ表面法の本態は，なお明らかでないがスク 
リーニング法としても, やはり検討を必要とする点がな お多い上いえる。

次に「飽食試験」において，「尿糖と皮ふ表面法」之 の関連を例示する。

62才，男子では尿糖，皮ふ表面法ともに陽性（図 No. 46)，一方35才，女子では尿糖のみ陽性，皮ふ表面 法はすべて陰性（困No. 47），という成績である。

図No. 47 飽食試験と皮骨表面法（その 2)

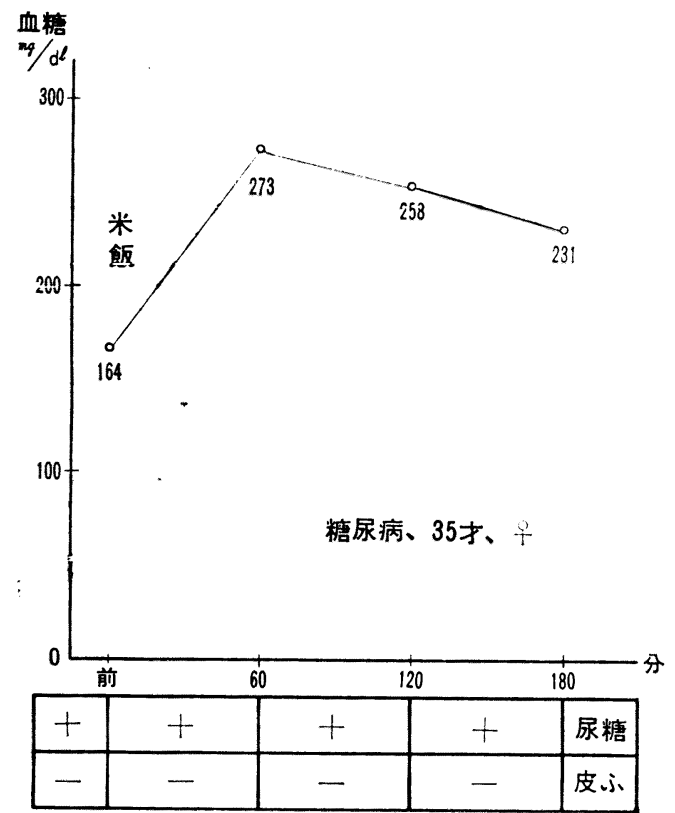

血糖曲線と比較して, 何故かかる差異が出てくるの か，皮ふ表面における糖代謝との関連が推定されるが, ここでは今後の検索にまちたいと考える。

以上スクリーニング法に対する私どあの検討の結果は

(1) 第一次検查において血糖は除外出来ない。

(2) スクリーニング法における簡易法の採用は，なお 検討の余地が多く，面倒でも精密法によるべきで ある。

(3) 糖尿病早期発見には, 集団検猃の励行之, 糖尿病 に対する啓蒙が極めて大切である。

ということに尽きるのである。

$$
\text { む す ひ }
$$

最後に私どあの報告を簡約する。

私どあは農村における糖尿病の実態把握を目的に，農 村医学的な立場で, 種々の統計的調査を中心として報告 した。その結果
(1) 農村においても，糖尿病の発生頻度は現在決して 低くない。

(2) 農村にお汀る糖尿病も，老年層，男性に多く，ま た無自覚性，未知患者が圧倒的に多い。

(3) 農村における糖尿病は, 男性に血管障害, 女性に 重症例が多い傾向を示している。

(4) 糖尿病発症要因のうち, 特に年令との関連性が強 い。即ち農村における人口老令化の一表現と屯思 水れる。

(5) 農村における糖尿病の早期発見, 早期治療には今 後集団検晾の励行, 糖尿病に対する啓蒙運動の推 進が望まれる。

(6) スクリーニング法に抢いて, 血糖は除外出来な い。しかも精密血糖法による測定が望ましい。 ということを強調し，あわせて「農村における糖尿病の 実態」が，今後益々解明されてゆくことを期待して，本 報告のむすびとする。

この報告を終るとあたり，この光喿する機会を与えられた鈴 木前学会長, 松尾現学会長, 岡本次期学会長はじめ, 会員の皆 様方湟く御礼申しあげます。

また本研究のため，終始御指導いただきました恩師 名古屋大 学第三内科山田弘三教授飞深謝致しま专。

さらと本研究に際し御援助いただきました各機関, 関係者の 方々に心より御礼申しあけます。

\section{本研究に御援助いただいた機関名}

〔北海道〕北海道大学・真下内科, 旭川厚生総合病院〔東北〕 岩手医科大学 - 木村内科, 市立水沢病院, 由利組合総合病院 [関東〕幸手病院 [信越〕佐久総合病院〔東海〕東海四県農村 医学会, 遠州総合病院, 三重中央総合病院, 員弁厚生病院, 愛 知県厚生農協連, 渥美病院, 無知眧和病院, 尾西病院, 知多厚 生病院, 愛知江南保健所〔近畿】京都府立医科大学 - 吉田内科 〔中国〕山口大学・藤田内科, 佐伯総合病院〔四国〕德島大学 - 油谷内科〔九州〕 熊本大学・体質医学研究所, 大分鶴見病院

\section{文献}

1）有本邦太郎：農村の栄荃とその改善, 農村医学, 13(1): 3, 吗40.12.

2) Camerini-Davàlos, R. A. etal : preliminary Observations on subjects with prediabetes, Diabetes, 12 : $508,1963$.

3) Duncan, G. G. : Diabetes mellitus. Diseases of metabolism (ed. by Duncan), W. B. Saunders, Co., philadelphia, 1952.（36）より引用

4）平田幸正：糖尿病喨療の実施, 東京, 金原出版 $\mathrm{KK}$. 
昭40. 10.

5）平田幸正：病気の診断基隼とその問題占，糖尿病，最新 医学, 21(4): 800, 昭41.4.

6）平田幸正他：糖尿病集団検診成績ならびそその経年観察， 日内会誌，52(2)：158，昭 38.5 .

7）堀内光：短期人間ドック，榶尿病の判定と管理，東京， 日本病院協会, 162 , 昭 40.8.

8）石井惕：血糖測定の精密法と簡易法の相関，日医事新報， 2201，124，昭41.7.2.

9）伊藤 裕一：岩手県純農村地区飞抢ける糖尿及び糖尿病, 農村医学, 13(1): 79, 昭40.12.

10）伊藤恭平他：糖尿病の病態汇関する臨床的観察

（1）当院飞括ける糖尿病患者の統計的調査, 農村医学, 11 (2)：129，昭38. 12 .

（2）当院飞特ける糖尿病患者の 2.3 代謝について，農 村医学, 12 (1): 19, 昭39.11.

（3）尾張北部一地区飞括ける 糖氺病集団倹猃成績飞つ いて, 農村医学, 13 (1): 77, 昭40.12.

（4）尾張部農村飞括ける糖尿病の分析, 農村医学, 第 14回総会抄録号, 24 , 昭 40.10.

（5）農村飞扣ける 糖尿病患者の脂質代謝分析, 農村医 学, 第15回総会抄録号, 23 , 昭41.8.

11）伊藤 恭平他：農村飞打ける 糖尿病患者の蛋白代謝飞つい $\tau$, 農村医学, $13(1): 80$, 昭40. 12.

12）伊藤 巷平他：農村飞おける 糖尿病患者の脂質代謝飞つい $\tau$, 農村医学, 第14回総会抄録号, 24, 昭40.10.

13）岩鶴龍三, 宮野義美: 糖尿病の診断と治療まで, 東京, 日本医書出版KK，昭 25 .

14) Joyner, R. E. : Reagent Strip method of Blood glucose Determination, J. Occupational med., 7:512. 1965.

15）笠原長寿：農村地帯分類，全共齐連月報， 161，14. 昭 37. 5 .

16）木村武他：岩手県下農山漁村の 糖尿病研究, 第 (3) 報, 糖尿病, 5：94，昭37.10.

第（4）報，糖尿病， $6(1) ： 62$ ，昭38. 11 .

17）小林芳人：日本飞㔚ける糖尿病の 頻度と早期治療, 第 15 回日本医学会総会学術集会記録, I $: 641$, 昭 34.

18）小林芳人：糖尿病集団検揨飞抢ける諸問題，第16回日本 医学会総会学術講演集, IV : 301 , 昭 38 .

19）国民衛生の動向：厚生の指標，11（11）:180，昭39.

20）呉真一他：農村の糖尿病の性格, 農村医学, 9 (3)：248, 昭36.3.

21）楠川晃：臨床と研究，34：247, 昭 32.

22）楠五郎雄, 平田幸正: 糖尿病, 東京, 医学書院, 昭35.
23）葛谷信貞：わが国化扣ける糖尿病患者の推移、医学のあ ゆみ，55（13）：括ほえがき。瞊40.12.25.

24）葛谷信貞他：梼尿病の再娭討，最新医学，19 (8)：2020 骂39. 8.

25）真下啓明他：北海道の一農村飞拈ける糖尿病集団怡診飞 ついて，糖尿病， 7 (2): 119，昭39.8.

26）松尾忠良他：農村飞おける糖尿病の集团烦郝

第 (1) 報, 農村医学, 12 (2)：86, 昭40.2.

第（2）報, 農村笑学, 13（2）: 147, 昭41. 4.

27）宮尾定信他：日本人の糖尿病（度学, 臨床的特徽）, 湸 燎, 18: 1486, 昭40. 10.

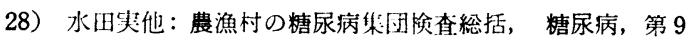
回総会抄録号, 17, 㒛41.5.

29）中川昌一他：過去 4 年䦐炕沏ける北海道地方の糖尿病集 団娭診成績飞ついて，楉尿病，8（1）：60，颔40.5.

30）中山光重他：日本飞的る糖尿病の頻度と特徵, 内科, 17 (2): 220, 炤41.2.

31）中山光重：人䦥ドック，精尿病，医学シンポジウム第26

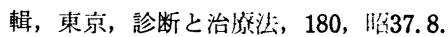

32) Philip Gerber. etal : Mass Screening for Diabetes Using a skin-Surface Test, J. A. M. W. A., 20 (9): 867, 1965.

33）坂口康蔵：本邦人の糖尿と糖尿病, 日内会誌, $24: 1$, 昭 11.

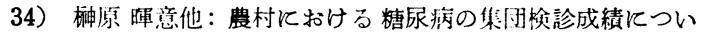
て, 農村医学, $10(3): 209$, 㫿37.8.

35）瀬木三雄他: 糖尿病の地理, 統计的観察, 糖尿病, 医学 シンポジゥム第17輯, 東京, 部断と治撩社, 13 , 昭32.

36) 竹田正次他: The Characteristics of Japanese Diabetes, 日内分泌誌，40 (9)：1145, 炤39.

37）上田英雄, 前沢秀憲: 楉尿病学, 東京, 南江堂, 昭 40 .

38) V. marks, A. Dawson : Rapid stick method for Determining Blood-glucose Concentration, Brit. Med. J., 1 (5430): 293, 1965.

39）和田正久, 中山幸二：成人病の発見から管理まで，糖尿 病, 東京, 医学書院, 174, 昭38.

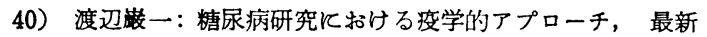
医学, 19 (6): 1432, 昭39.6.

41）山形敞一他：Dextrostix 飞よる血桾測定，日医事新報， 2207, 13, 昭41.8.13.

42）吉沢国雄他：長野県農村の糖尿病化関する研究，農村医 学, 12 (1): 18, 昭39.11.

43）油谷友三他：四国地方飞打ける糖尿病集団検䛦，第（2） 報, 四国医学誌, 17 (5)：307, 昭36. 10.

44）東海 4 県共同研究：シンポジウム，農村飞おける栯尿病 飞ついて, 第 4 回東海 4 県農村医学会総会, 昭41.6.26. 